\title{
Temporal and spatial variations in photosynthetic physiology of diatoms during the spring bloom in the western subarctic Pacific
}

\author{
Naoki Yoshie ${ }^{1,2,3, *}$, Koji Suzuki $^{4}$, Akira Kuwata ${ }^{2}$, Jun Nishioka $^{5}$, Hiroaki Saito ${ }^{2}$ \\ ${ }^{1}$ Division of Coastal Oceanography, Center for Marine Environmental Studies, Ehime University, 2-5 Bunkyo-cho, \\ Matsuyama 790-8577, Japan \\ ${ }^{2}$ Tohoku National Fisheries Research Institute, Fisheries Research Agency, 3-27-5 Shinhama-cho, Shiogama 985-0001, Japan \\ ${ }^{3}$ Japan Society for the Promotion of Science, 6 Ichibancho, Chiyoda-ku, Tokyo 102-8471, Japan \\ ${ }^{4}$ Faculty of Environmental Earth Science, Hokkaido University, N10W5 Kita-Ku, Sapporo 060-0810, Japan \\ ${ }^{5}$ Institute of Low Temperature Science, Hokkaido University, N19W8 Kita-Ku, Sapporo 060-0819, Japan
}

\begin{abstract}
Variations in photosynthetic parameters of phytoplankton during the spring bloom were investigated in the western subarctic Pacific. Light-saturated maximum photosynthesis rate $\left(P_{\max }^{\mathrm{B}}\right)$ and light-limited slope $\left(\alpha^{\mathrm{B}}\right)$ in the photosynthesis-irradiance $(P-E)$ curve were almost constant in the first half of the bloom and then concurrently increased by 5 times in the latter half with a constant light-saturation index $\left(E_{\mathrm{k}}=P_{\text {max }}^{\mathrm{B}} / \alpha^{\mathrm{B}}\right)$. In contrast, the maximum photochemical quantum efficiency $\left(F_{\mathrm{v}} / F_{\mathrm{m}}\right)$ of the algal photosystem II increased in the first half and thereafter decreased. Water temperature significantly affected the covariation in $P^{\mathrm{B}}{ }_{\max }$ and $\alpha^{\mathrm{B}}$ (i.e. $E_{\mathrm{k}}$-independent variability), suggesting that dark reaction processes in photosynthesis mainly regulated the changes in the $P$ - $E$ parameters. Although influences of nitrate, silicic acid, and dissolved iron on the $P$ - $E$ parameters were not observed, the elevated ammonium levels found in the latter half of the bloom could contribute to the $E_{\mathrm{k}}$-independent variability. There was no significant relationship among algal net growth rate, $P^{\mathrm{B}}{ }_{\max }$ and $\alpha^{\mathrm{B}}$ throughout the observations. Since most ecosystem models have used a constant $\alpha^{\mathrm{B}}$, parallel changes in $P^{\mathrm{B}}{ }_{\max }$ and $\alpha^{\mathrm{B}}$ should be taken into account in models reproducing ecosystem dynamics during spring diatom blooms.
\end{abstract}

KEY WORDS: Iron $\cdot P$-E curve $\cdot$ Photosynthesis $\cdot$ Spring bloom $\cdot$ Western North Pacific

Resale or republication not permitted without written consent of the publisher

\section{INTRODUCTION}

Phytoplankton photosynthesis is an essential process for marine food web dynamics and biogeochemical cycles. In order to express the influence of light intensity on photosynthesis rate, the photosynthesis-irradiance $(P-E)$ relationship is used. The $P$-E relationship is generally represented by 2 photosynthetic parameters: light-saturated maximum rate of photosynthesis, $P^{\mathrm{B}}$ max and light-limited slope, $\alpha^{\mathrm{B}}$, normalized by the chlorophyll a (chl a) concentration (e.g. Falkowski \& Raven 2007). Their ratio (i.e. $P_{\text {max }}^{\mathrm{B}} / \alpha^{\mathrm{B}}$ ) indicates the light intensity at which photosynthesis starts to become saturated, and is called the light-saturation index, $E_{\mathrm{k}}$ ( $\mu$ mol photons $\mathrm{m}^{-2} \mathrm{~s}^{-1}$ ). $P^{\mathrm{B}}{ }_{\max }$ and $\alpha^{\mathrm{B}}$ are variable with environmental conditions and phytoplankton community structures. They change with water temperature (Côté \& Platt 1983), light intensity (Van Oijen et al. 2005), macronutrient level (Platt et al. 1992), dissolved iron (D-Fe) concentration (Greene et al. 1991), and taxonomic composition of phytoplankton assemblage (Claustre et al. 1997). According to Behrenfeld et al. (2004), variability of $P^{\mathrm{B}}$ max and $\alpha^{\mathrm{B}}$ can be separated into 2 categories: one group is associated with changes in 
only $P_{\text {max }}^{\mathrm{B}}$ (i.e. constant $\alpha^{\mathrm{B}}$ and variable $E_{\mathrm{k}}$ Nielsen \& Jørgensen 1968), and the other group refers to parallel changes in $P^{\mathrm{B}}$ max and $\alpha^{\mathrm{B}}$ (i.e. constant $E_{\mathrm{k}}$ Platt \& Jassby 1976, Moline et al. 1998). The former variation $\left(E_{\mathrm{k}}-\right.$ dependent variability) is mainly caused by photoacclimation of phytoplankton (i.e. physiological adjustments in response to light conditions, Geider et al. 1998, Flynn 2001), while physiological mechanisms causing the latter variation $\left(E_{\mathrm{k}}\right.$-independent variability) are not well understood (Behrenfeld et al. 2004).

An ecosystem model is a powerful tool to understand the ecosystem dynamics and to examine factors controlling their variations. The outputs of the ecosystem model are largely influenced by the parameter values selected, and $P_{\text {max }}^{\mathrm{B}}$ and $\alpha^{\mathrm{B}}$ are important parameters (Fasham et al. 1990, Kuroda \& Kishi 2004, Yoshie et al. 2007). Also, selecting the variation type of $P^{\mathrm{B}}{ }_{\max }$ and $\alpha^{\mathrm{B}}$, i.e. whether they show $E_{\mathrm{k}}$-dependent variability (constant $\alpha^{\mathrm{B}}$ ) or $E_{\mathrm{k}}$-independent variability (covariation in $P_{\text {max }}^{\mathrm{B}}$ and $\alpha^{\mathrm{B}}$ ) influences the performance of the model, especially for the response of the ecosystem to environmental variations. Although such ecosystem models were recently applied to the western subarctic Pacific (Yoshie et al. 2003, Yamanaka et al. 2004), P-E measurements have seldom been conducted in that area (Yokouchi et al. 1997, Furuya et al. 1998), and variability of $P$-E parameters and their controlling factors are not well understood.

The Oyashio is a cold western boundary current of the North Pacific (Fig. 1). The Oyashio water is formed

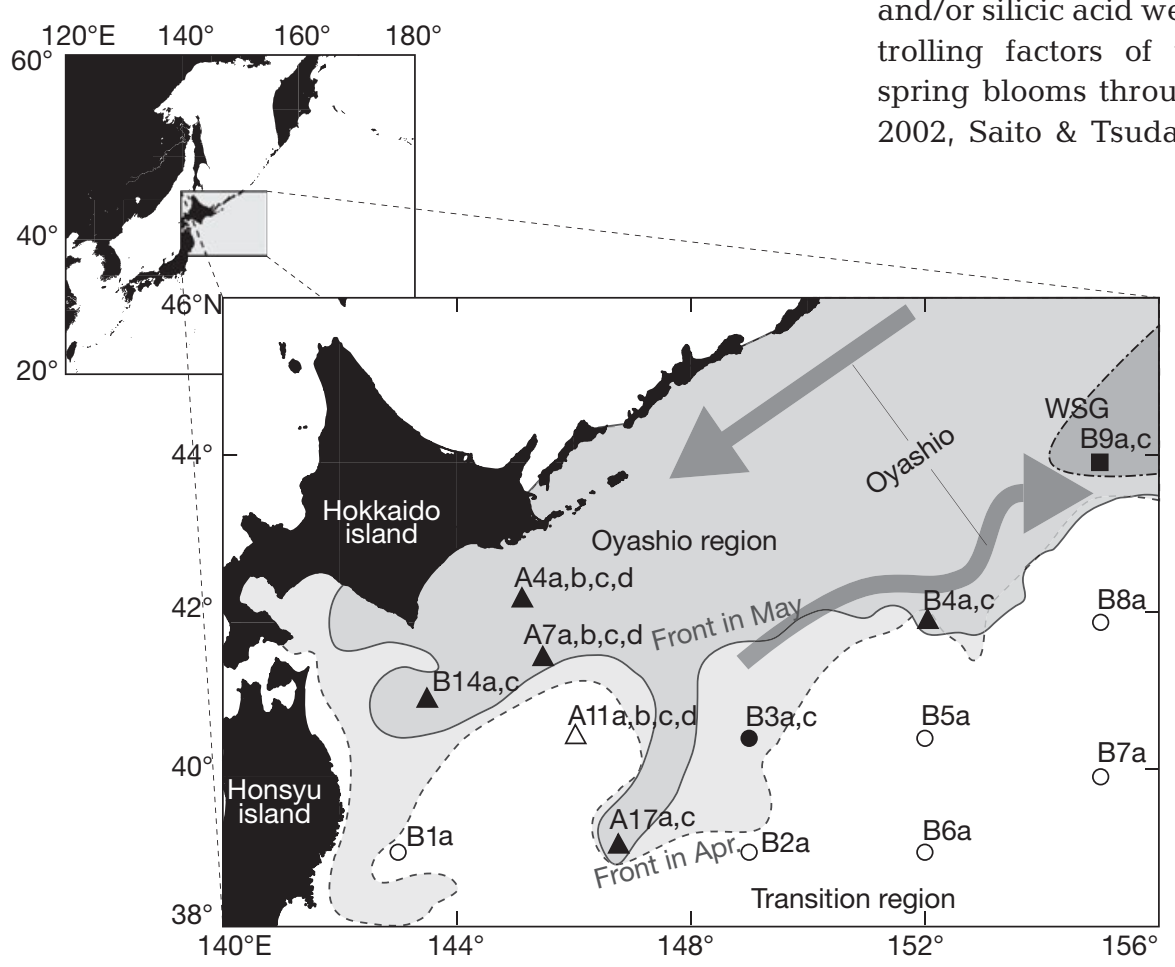

by mixing the subarctic water from the East Kamchatka Current and the Okhotsk water. A part of the Oyashio water flows southward across the subarctic front and mixes with subtropical Kuroshio water. The water mixing region is called the Kuroshio-Oyashio transition region (hereafter Transition region). The water properties of the Transition region are characterized by being warm, saline, and having low nutrient concentrations compared to the Oyashio region (Yasuda 2003). The other hydrographical characteristics of the Transition region are a deep seasonal mixed layer that is induced by winter cooling at the sea surface of saline subtropical water overlaid on fresh Oyashio water. As a result of different hydrographical properties, nutrients and plankton show different seasonal dynamics between the Oyashio and the Transition regions (Saito et al. 1998).

Despite the differences in hydrographical characteristics between the Oyashio and Transition regions, large phytoplankton blooms dominated by diatoms occur in both regions every spring. Taniguchi (1999) pointed out the high energy-transfer efficiency from primary production to higher trophic levels in the Oyashio and the Transition regions, and this is an important factor in the formation of this highly productive fishing ground. In addition, since spring diatom blooms take up large amounts of nutrients (including dissolved inorganic carbon) in the Oyashio and Transition regions and significantly affect the biogeochemical cycles, nutrient and plankton dynamics during spring blooms have been investigated. Light, iron, and/or silicic acid were proposed as the important controlling factors of the ecosystem dynamics during spring blooms through field observations (Saito et al. 2002, Saito \& Tsuda 2003, Nishioka et al. 2007), and

Fig. 1. Sampling stations. Distributions of the Oyashio region in April and May are outlined by light gray and mid gray shading, respectively. The Western subarctic gyre (WSG) is shaded dark gray. The Oyashio current is represented by the dark gray arrows. (ム) diatom bloom stations in the Oyashio; $(\Delta)$ diatom bloom stations in the Transition; $(O)$ stations in the Transition; (๑) stations in the Oyashio; (ם) stations in the WSG. The subscripts at each station show the sampling periods: (a) first period in April; (b) second period in April; (c) first period in May; (d) second period in May 
ecosystem models (Yoshie et al. 2003, Yamanaka et al. 2004, Yoshie \& Yamanaka 2005). However, the limited understanding of $P$ - $E$ parameters such as $P^{\mathrm{B}}$ max and $\alpha^{\mathrm{B}}$ prevents further evaluation of the ecosystem model and determination of the factors controlling the ecosystem dynamics in these regions. Smetacek (1999) pointed out by reviewing recent studies on biogeochemical models that new production during diatom blooms was among the most important processes for marine biogeochemical cycles, and physiological information on bloom-forming diatoms would be essential for the improvement of the models.

In this study, we carried out 2 cruises in the Oyashio and the Transition regions to examine the temporal and geographical variations in $P$-E parameters with reference to environmental conditions. Furthermore, relationships among the $P$-E parameters, other photosynthetic parameters, and environmental conditions were investigated. Finally, the variation patterns of the $P$-E parameters and their controlling factors are discussed.

\section{MATERIALS AND METHODS}

Sampling and hydrographical analysis. Field observations were performed in the Oyashio and Transition regions off Hokkaido, Japan, during 11 to 25 April and 7 to 19 May 2003 (Fig. 1). We visited 3 stations (A4, A7, and A11) 2 times during each cruise. Temperature and salinity were measured with a CTD system (SBE 911 plus, Sea-Bird Electronics). Areas where the temperature at $100 \mathrm{~m}$ depth was $<5^{\circ} \mathrm{C}$ were defined as the Oyashio region, and $>5^{\circ} \mathrm{C}$ at $100 \mathrm{~m}$ as the Transition region (Kawai 1972). The mixed layer depth (MLD) was estimated using the definition: depth at which the water density $=$ the density $+0.1 \sigma_{\theta}$ of the sea-surface water. Water samples were collected using trace-metal-clean Niskin-X samplers on a Kevlar hydrowire (Nishioka et al. 2007). Underwater downward irradiance of photosynthetically available radiation (PAR) was measured by a spectroradiometer (PRR-600/610, Biospherical Instruments). The euphotic layer depth (ELD; $1 \%$ light depth relative to the sea surface) was estimated from the vertical profile of PAR. Incident PAR was measured with a LiCor PAR sensor LI-190SA, averaged for $10 \mathrm{~min}$, and recorded using a data logger. Macronutrient samples were frozen in a deep freezer $\left(-85^{\circ} \mathrm{C}\right)$ and measured in an onshore laboratory using a nutrient analyzer (AACS; BRAN+LUEBBE). D-Fe concentration was determined using an automatic iron analyzer (Kimoto Electric) equipped with a chelating resin column of 8hydroxyquinoline (Obata et al. 1993). All D-Fe data are from Nishioka et al. (2007).
Photosynthesis and irradiance curve. Photosynthetic rates of the phytoplankton community were determined using the ${ }^{13} \mathrm{C}$ technique (Hama et al. 1983). Water samples were collected from $10 \mathrm{~m}$ at various times of the day, and these were dispensed into ten $275 \mathrm{ml}$ polystyrene bottles; $1.00 \mathrm{ml}$ of $\mathrm{NaH}^{13} \mathrm{CO}_{3}$ solution $\left({ }^{13} \mathrm{C}\right.$ concentration: $\left.58.2 \mathrm{mmol} \mathrm{l}^{-1}\right)$ was injected into each bottle (i.e. the isotopic ratio of ${ }^{13} \mathrm{C}:{ }^{12} \mathrm{C}$ in the bottle became approximately $10 \%$ ). Incubations were conducted for $2 \mathrm{~h}$ under a series of irradiances (ca. 3, 6, $10,30,70,140,280,560,1200$, and $3000 \mu \mathrm{mol}$ photons $\mathrm{m}^{-2} \mathrm{~s}^{-1}$ ) in an incubator. The light source of the incubator was a $150 \mathrm{~W}$ metal-halide lamp (HQI-T 150W/ WDL/UVS, color temperature: 3000K, Mitsubishi Osram), and the light intensities were controlled with neutral density filters. The irradiances in each bottle were periodically determined with a $4 \pi$ PAR sensor (QSL-2101, Biospherical Instruments). The incubator was maintained at the in situ temperature using a temperature-controlled water bath. After the incubation, water samples in each bottle were filtered onto precombusted Whatman GF/F filters under gentle vacuum $(<100 \mathrm{~mm} \mathrm{Hg})$. The filters were stored in liquid nitrogen or a deep-freezer $\left(-85^{\circ} \mathrm{C}\right)$ until analysis. After removal of unfixed inorganic carbon with concentrated $\mathrm{HCl}$ fumes, the filters were dried in a vacuum desiccator. The isotopic ratio of ${ }^{13} \mathrm{C}:{ }^{12} \mathrm{C}$ and the amount of particulate organic carbon (POC) were determined using a mass spectrometer with an elemental analyzer (ANCA-SL stable isotope analysis system, Europa Scientific). The amount of dissolved inorganic carbon in seawater was determined with a coulometer (Model 5012, UIC). Dark bottles as controls were not prepared in this study. The photosynthetic parameters, lightsaturated maximum rate of photosynthesis $\left(P^{\mathrm{B}}{ }_{\text {max }}: \mathrm{mg}\right.$ $\mathrm{C}[\mathrm{mg} \mathrm{chl}]^{-1} \mathrm{~h}^{-1}$ ) and light-limited slope of the $P-E$ curve $\left(\alpha^{\mathrm{B}}: \mathrm{mg} \mathrm{C}[\mathrm{mg} \mathrm{chl}]^{-1} \mathrm{~h}^{-1}\left[\mu \mathrm{mol} \text { photons } \mathrm{m}^{-2} \mathrm{~s}^{-1}\right]^{-1}\right)$ were calculated by fitting experimental data to the exponential photoinhibition model of Platt et al. (1980) using the Levenberg-Marquardt method (KaleidaGraph 4.0, Synergy Software):

$$
P^{\mathrm{B}}=P_{\mathrm{S}}^{\mathrm{B}}\left(1-\mathrm{e}^{\left(-\alpha^{\mathrm{B}} E / P_{\mathrm{S}}^{\mathrm{B}}\right)}\right)\left(\mathrm{e}^{\left(-\beta^{\mathrm{B}} E / P_{\mathrm{S}}^{\mathrm{B}}\right)}\right)
$$

$P^{\mathrm{B}}\left(\mathrm{mg} \mathrm{C}[\mathrm{mg} \mathrm{chl}]^{-1} \mathrm{~h}^{-1}\right)$ is the observed photosynthetic rate, $E\left(\mu \mathrm{mol}\right.$ photons $\mathrm{m}^{-2} \mathrm{~s}^{-1}$ ) is the irradiance at the incubator, $\beta^{\mathrm{B}}\left(\mathrm{mg} \mathrm{C}[\mathrm{mg} \mathrm{chl}]^{-1} \mathrm{~h}^{-1}\left[\mu \mathrm{mol}\right.\right.$ photons $\mathrm{m}^{-2}$ $\left.\left.\mathrm{s}^{-1}\right]^{-1}\right)$ is a photoinhibition parameter, and $P^{\mathrm{B}}$ (mg C [mg chl $]^{-1} \mathrm{~h}^{-1}$ ) is the theoretical maximum photosynthetic rate if $\beta^{B}$ was 0 . Superscript B denotes parameters normalized to chl a concentration determined by HPLC. $P^{\mathrm{B}}{ }_{\max }$ was calculated from the following equation:

$$
P_{\max }^{\mathrm{B}}=P_{\mathrm{S}}^{\mathrm{B}}\left[\alpha^{\mathrm{B}} /\left(\alpha^{\mathrm{B}}+\beta^{\mathrm{B}}\right)\right]\left[\beta^{\mathrm{B}} /\left(\alpha^{\mathrm{B}}+\beta^{\mathrm{B}}\right)\right]^{\left(\beta^{\mathrm{B}} / \alpha^{\mathrm{B}}\right)}
$$


The light-saturation index $\left(E_{\mathrm{k}}\right.$ : $\mu \mathrm{mol}$ photons $\left.\mathrm{m}^{-2} \mathrm{~s}^{-1}\right)$ was obtained from $P^{\mathrm{B}}{ }_{\text {max }}$ and $\alpha^{\mathrm{B}}\left(E_{\mathrm{k}}=P^{\mathrm{B}}{ }_{\max } / \alpha^{\mathrm{B}}\right)$. The $P$ $E$ parameters for the 3 regions were determined a total of 19 times (Oyashio: 10, Transition: 7, and Western subarctic gyre [WSG]: 2). The averaged SE of $P^{\mathrm{B}}{ }_{\max }, \alpha^{\mathrm{B}}$, and $\beta^{B}$ in the curve fittings were 8,12 , and $33 \%$, respectively.

Primary production. Primary production (PP: mg C $\mathrm{m}^{-3} \mathrm{~d}^{-1}$ ) was determined with a simulated in situ incubation method following the protocol for the Joint Global Ocean Flux Study (JGOFS; Knap et al. 1996) except the ${ }^{13} \mathrm{C}$ uptake technique (Hama et al. 1983). Water samples were collected from 50 and $5 \%$ light depths a total of 15 times (Oyashio: 9, Transition: 4, WSG: 2). The samples $(300 \mathrm{ml})$ were filtered onto precombusted Whatman GF/F filters under gentle vacuum ( $<100 \mathrm{~mm} \mathrm{Hg}$ ). The filters were stored in liquid nitrogen or a deep-freezer $\left(-85^{\circ} \mathrm{C}\right)$ until analysis. POC and its carbon isotopic composition on the filters were determined as in the $P$-E experiment described above. PP was calculated following the procedure of Hama et al. (1983). The growth rates of the phytoplankton assemblage were estimated from the PP and the POC (i.e. growth rate $=P P / P O C: \mathrm{d}^{-1}$ ) assuming the POC was mainly composed of active phytoplankton cells. The growth rate could be underestimated due to the other origins of POC (e.g. microzooplankton and detritus). The values of the $\mathrm{PP}, \mathrm{POC}$, and growth rate at $10 \mathrm{~m}$ depth were linearly interpolated from those at 50 and $5 \%$ light depths. The assimilation number (Assim. No.) of the phytoplankton assemblage at $10 \mathrm{~m}$ depth was also determined from the PP and the chl $a$ concentration (i.e. Assim. No. = PP/chl a: $\mathrm{mgC}[\mathrm{mg}$ $\mathrm{Chl}]^{-1} \mathrm{~d}^{-1}$ ).

Chl $a$ and accessory pigments. Concentrations of chl $a$ and accessory pigments were determined by HPLC following the procedure of Suzuki et al. (2005). Water samples (1 l) were filtered onto Whatman GF/F filters (25 $\mathrm{mm}$ in diameter) under low vacuum ( $<100 \mathrm{~mm} \mathrm{Hg}$ ). The filters were frozen in liquid nitrogen or the deep-freezer until analysis, then soaked in $3.0 \mathrm{ml} N, N$-dimethylformamide (DMF), sonicated with an ultrasonic homogenizer (SONIFIER model 250, Branson) and extracted for $2 \mathrm{~h}$ in the dark at $-20^{\circ} \mathrm{C}$. The extract was filtered through $0.45 \mu \mathrm{m}$ PTFE filters to remove fine particles. The HPLC system (CLASS-VP system including a photodiode array detector, Shimadzu; Spherisorb ODS2 column: $5 \mu \mathrm{m}$ particle size, $4.6 \times 250 \mathrm{~mm}$, Waters) was calibrated with pure standards whose concentrations were determined spectrophotometrically, and canthaxanthin was added to each sample as an internal standard. Details of the pigment data (K. Suzuki et al. unpubl.) will be reported elsewhere. Phytoplankton community structure was estimated by using the pigment data determined by
HPLC and the CHEMTAX program (Mackey et al. 1996). Initial pigment:chl a ratios and the other settings were derived from Suzuki et al. (2002a), as used previously for CHEMTAX analysis in the subarctic North Pacific. The CHEMTAX outputs were also validated by comparison to the cell density data from the microscopic observations.

Stations where diatoms were blooming are defined in this study as fulfilling 2 conditions: (1) cell density of diatoms with $>10^{5}$ cells $\mathrm{l}^{-1}$ and (2) diatom contributions with $>45 \%$ of the total phytoplankton assemblage as estimated by CHEMTAX.

Light absorption coefficient of phytoplankton. The light absorption coefficient of phytoplankton was determined with the glass-fiber filter technique (Kishino et al. 1985, Cleveland \& Weidemann 1993). Water samples $(500 \mathrm{ml})$ were filtered onto GF/F filters (25 $\mathrm{mm}$ in diameter) with gentle vacuum. The filters were frozen in liquid nitrogen and kept in the deepfreezer. After return to the laboratory, the filters were bleached using $1 \%$ sodium hypochlorite $(\mathrm{NaClO}$; Tassan \& Ferrari 1995), and the light absorption spectra of the phytoplankton collected on the filter between 400 and $700 \mathrm{~nm} a_{\mathrm{ph}}(\lambda)\left(\mathrm{m}^{-1}\right)$ were measured spectrophotometrically (UV-2450, Shimadzu) with $1 \mathrm{~nm}$ resolution. The light absorption coefficient of phytoplankton was converted to chl a-specific absorption coefficient $a^{*}{ }_{\mathrm{ph}}(\lambda)\left(\mathrm{m}^{2}[\mathrm{mg} \mathrm{chl}]^{-1}\right)$, i.e. we divided $a_{\mathrm{ph}}(\lambda)$ by chl $a$ concentration determined by HPLC. The spectrally weighted chl a specific absorption coefficient of phytoplankton $\left(\bar{a}^{*}{ }_{\mathrm{ph}}: \mathrm{m}^{2}[\mathrm{mg} \mathrm{chl}]^{-1}\right)$, which took into account the actual spectral distribution $E(\lambda)$ of the PAR (from 400 to $700 \mathrm{~nm}$ ) in the incubator, was calculated as:

$$
\bar{a}^{*}{ }_{\mathrm{ph}}=\frac{\int_{400}^{700} a^{*}{ }_{\mathrm{ph}}(\lambda) E(\lambda) \mathrm{d} \lambda}{\int_{400}^{700} E(\lambda) \mathrm{d} \lambda}
$$

Maximum quantum yield of photosynthesis ( $\Phi_{\max }$ : mol C mol photon $\left.{ }^{-1}\right)$ was calculated from $\alpha^{\mathrm{B}}(\mathrm{mg} \mathrm{C}[\mathrm{mg}$ $\mathrm{chl}]^{-1} \mathrm{~h}^{-1}$ [ $\mathrm{mmol}$ photons $\left.\left.\mathrm{m}^{-2} \mathrm{~s}^{-1}\right]^{-1}\right)$ and $\overline{\mathrm{a}}^{*}{ }_{\mathrm{ph}}\left(\mathrm{m}^{2}[\mathrm{mg}\right.$ chll $\left.]^{-1}\right)$ :

$$
\Phi_{\max }=0.0231\left(\alpha^{\mathrm{B}} / \overline{\mathrm{a}}^{*}{ }_{\mathrm{ph}}\right)
$$

The factor 0.0231 converts grams to moles and hours to seconds. Absorption-based light-saturated photosynthetic rates $\left(P_{\text {max }}^{*}: \mu\right.$ mol $\left.\mathrm{C} \mathrm{m}^{-2} \mathrm{~s}^{-1}\right)$ were also calculated from $P^{\mathrm{B}}{ }_{\max }$ and $\overline{\mathrm{a}}^{*}{ }_{\mathrm{ph}}$ :

$$
P^{*}{ }_{\max }=0.0231\left(P_{\max }^{\mathrm{B}} / \bar{a}^{*}{ }_{\mathrm{ph}}\right)
$$

Fast repetition rate fluorometry. The maximum photochemical quantum efficiency of phytoplankton photosystem II $\left(F_{\mathrm{v}} / F_{\mathrm{m}}\right)$, where $F_{\mathrm{v}}$ is the difference between the maximum $\left(F_{\mathrm{m}}\right)$ and minimum $\left(F_{0}\right)$ chlorophyll fluorescence yield, was measured by bench-top fast repetition rate (FRR) fluorometry (Kolber et al. 
1998). The functional absorption cross-section of photosystem II $\left(\sigma_{\mathrm{PSII}}: \mathrm{m}^{2}\right.$ photon $\left.{ }^{-1}\right)$ was also determined by this technique. Water samples at various times in the day were transferred into acid-cleaned polypropylene bottles and acclimated in the dark for $30 \mathrm{~min}$ in an incubator, which was adjusted to the in situ seawater temperature. Variable fluorescence of phytoplankton was measured with an FRR fluorometer (FastTracka, Chelsea Technologies Group) in a dark room following the method of Suzuki et al. (2002b). In brief, the FRR fluorometer was set to deliver saturation flash sequences of 100 flashes ( $1 \mu$ s duration) with $1 \mu$ s intervals between flashes. Acquisitions of a series of 16 flash sequences were internally averaged and were repeated 5 times with a $1 \mathrm{~s}$ interval between iterations. Sample blanks using filtered seawater were not prepared, and the effects on the measurements of variable fluorescence were ignored in this study, because fluorescence signals from the seawater samples were much higher than those from the blanks (cf. Laney \& Letelier 2008). The fluorescence data were processed with FRS Software (Chelsea Technologies Group) to obtain $F_{\mathrm{v}} / F_{\mathrm{m}}$ and $\sigma_{\text {PSII. }}$

Index for the development of spring diatom blooms. Observations repeated seasonally from 1990 to 1999 in the Oyashio region (e.g. Limsakul et al. 2002, Saito et al. 2002) revealed that decreases in silicic acid in the mixed layer during spring was mainly due to the uptake by bloom-forming diatoms. In the present study, the development stage of the spring diatom bloom is defined by the disappearance of silicic acid in the mixed layer from the initial concentration supplied in winter. As the mixed layer during winter in both regions was deeper than $100 \mathrm{~m}$ (ca. 100 to $300 \mathrm{~m}$ depth) and the maximum of the euphotic layer was shallower than $70 \mathrm{~m}$, stable silicic acid concentration can be expected at $100 \mathrm{~m}$ depth from winter to spring. We assumed the concentration at $100 \mathrm{~m}$ as the initial salicic acid concentration and defined an index for the development of spring diatom blooms $\left(I_{\text {devel }}\right)$ using a ratio of the disappearance of silicic acid to initial silicic acid concentration in the mixed layer as follows:

$$
I_{\text {devel }}=\left(\frac{\mathrm{MLD} \times[\mathrm{Si}(\mathrm{OH}) 4] 100 \mathrm{~m}-\int_{0 \mathrm{~m}}^{\mathrm{MLD}}[\mathrm{Si}(\mathrm{OH}) 4]_{z} \mathrm{~d} z}{\mathrm{MLD} \times[\mathrm{Si}(\mathrm{OH}) 4] 100 \mathrm{~m}}\right)
$$

where $\left[\mathrm{Si}(\mathrm{OH})_{4}\right]_{100 \mathrm{~m}}$ is the concentration of silicic acid at $100 \mathrm{~m}$ depth, and $\left[\mathrm{Si}(\mathrm{OH})_{4}\right]_{z}$ is the concentration of silicic acid at $z \mathrm{~m}$ depth. For example, $I_{\text {devel }}=0.5$ means that a half of the silicic acid supplied in the winter was consumed by diatoms in the mixed layer. Here diatom blooms are classified into the following 3 stages: prebloom $\left(I_{\text {devel }}<0.15\right)$, growth phase of the bloom $\left(I_{\text {devel }}=\right.$ 0.15 to 0.50$)$, and decline phase of the bloom $\left(I_{\text {devel }}>\right.$ $0.50)$.

\section{RESULTS}

\section{Spatiotemporal changes in environmental conditions and photosynthetic parameters}

The daily flux of incident PAR ranged from 19 to 50 mol photons $\mathrm{m}^{-2} \mathrm{~d}^{-1}$, and the maximum incident PAR was $1927 \mu \mathrm{mol}$ photons $\mathrm{m}^{-2} \mathrm{~s}^{-1}$ during the 2 cruises. There were no significant differences in the incident PAR between the Oyashio, WSG, and Transition regions. Large-scale phytoplankton blooms dominated by neritic chain-forming diatoms were observed in the Oyashio region (Fig. 1), and the species composition of diatoms was similar among the stations. On the other hand, pelagic chain-forming diatoms dominated in the Transition region (Fig. 1), and the magnitude of the diatom blooms was relatively low compared to the Oyashio region ([Chl a] in the growth phase in Table 1). In the WSG, no diatom blooms were observed during the 2 cruises.

The physical, chemical, and biological conditions clearly changed associated with the development of the spring diatom bloom. During the pre-bloom, seasurface temperatures in the Oyashio region were colder than those in the Transition region (Table 1, Fig. 2a). The mean MLDs in the Oyashio region were about half those of the Transition region, and they were deeper than the mean ELD (Table 1). Large spatial variations in the MLD were observed even in the same region, which is a physical characteristic in the early spring in the western North Pacific (T. Kono \& M. Sato unpubl.). Daily irradiance flux vertically averaged in the mixed layer $\left(\mathrm{PAR}_{\mathrm{ML}}\right)$ was low (Table 1 ) in the pre-bloom condition, except at 2 stations that had high $\mathrm{PAR}_{\mathrm{ML}}$ due to the relatively shallow mixed layer compared to the euphotic layer (Fig. 2b). Concentrations of nitrate and silicic acid in the Oyashio region were 1.6 times higher than those in the Transition region (Table 1, Fig. 2c,e). The D-Fe concentrations were also 1.8 times higher in the Oyashio region than in the Transition region (Table 1, Fig. 2f). Chl a concentrations, diatom fractions, $\mathrm{PP}$, and algal growth rates in the Oyashio and Transition regions were similar to each other (Fig. $2 g-j$ ).

An example of the $P-E$ curve fitting is plotted in Fig. 3. The photosynthetic parameters in both regions also showed similar values in the pre-bloom phase (Fig. 4). The $P_{\text {max }}^{\mathrm{B}}, \alpha^{\mathrm{B}}$, and $\Phi_{\max }$ were low and showed minimal variation between stations (Fig. 4a,b,d). On the other hand, $\beta^{\mathrm{B}}$ was $60 \%$ smaller in the Oyashio region than in the Transition region (Table 1$) . F_{\mathrm{v}} / F_{\mathrm{m}}$ and $\sigma_{\mathrm{PSII}}$ in both regions were similar to each other (Table 1, Fig. 4e). In the WSG, the environmental conditions and the photosynthetic parameters were comparable to those in the Oyashio region except for the 
Table 1. Environmental conditions and photosynthetic parameters in the Oyashio region, western subarctic gyre (WSG), and Transition region. $I_{\text {devel }}$ : developmental index of the spring bloom; Temp.: temperature $\left({ }^{\circ} \mathrm{C}\right) ;$ MLD: mixed layer depth $(\mathrm{m})$; ELD: euphotic layer depth $\left(\mathrm{m}, 1 \%\right.$ light depth); $\mathrm{PAR}_{\mathrm{ML}}$ : vertically averaged photosynthetically available radiation in MLD (mol photons $\left.\mathrm{m}^{-2} \mathrm{~d}^{-1}\right)_{i}\left[\mathrm{NO}_{3}\right],\left[\mathrm{NH}_{4}\right]$, and [ $\left.\mathrm{Si}(\mathrm{OH})_{4}\right]$ : macro nutrient concentration $\left(\mu \mathrm{mol} \mathrm{l} \mathrm{l}^{-1}\right) ;\left[\mathrm{D}\right.$-Fe]: dissolved iron concentration $\left(\mathrm{nmol} \mathrm{l}^{-1}\right.$, data from Nishioka et al. 2007); [chl a]: chlorophyll a concentration ( $\left.\mu \mathrm{g} \mathrm{l}^{-1}\right)$; Diatom\%: diatom fraction from CHEMTAX (\%); Prim. Prod.: primary production (mg C m $\left.{ }^{-3} \mathrm{~d}^{-1}\right)$; Assim. No.: assimilation number $\left(\mathrm{mg} \mathrm{C}\left[\mathrm{mg} \mathrm{chl}^{-1} \mathrm{~d}^{-1}\right)\right.$; Growth rate $\left(\mathrm{d}^{-1}\right)$; $P^{\mathrm{B}}$ max: lightsaturated maximum rate of photosynthesis $\left(\mathrm{mg} \mathrm{C}\left[\mathrm{mg} \mathrm{chl}^{-1} \mathrm{~h}^{-1}\right) ; \alpha^{\mathrm{B}}\right.$ : light-limited slope of the photosynthesis-irradiance $(P$ - $E)$ curve $\left(\mathrm{mg} \mathrm{C}[\mathrm{mg} \mathrm{chl}]^{-1} \mathrm{~h}^{-1}\left[\mu \mathrm{mol} \text { photons } \mathrm{m}^{-2} \mathrm{~s}^{-1}\right]^{-1}\right) ; \beta^{\mathrm{B}}$ : photoinhibition parameter $\left(\mu \mathrm{g} \mathrm{C}[\mathrm{mg} \mathrm{chl}]^{-1} \mathrm{~h}^{-1}\left[\mu \mathrm{mol} \text { photons } \mathrm{m}^{-2} \mathrm{~s}^{-1}\right]^{-1}\right) ;$ $E_{\mathrm{k}}$ : light-saturation index ( $\mu \mathrm{mol}$ photons $\left.\mathrm{m}^{-2} \mathrm{~s}^{-1}\right) ; \bar{a}^{*}{ }_{\mathrm{ph}}$ : spectrally weighted average chl a spectral absorption coefficient $\left(\mathrm{m}^{2}[\mathrm{mg}\right.$ $\left.\mathrm{chl}]^{-1}\right)_{;} \Phi_{\max }$ : maximum quantum yields $\left(\mathrm{mol} \mathrm{C} \text { mol photon }{ }^{-1}\right)_{i} P^{*}$ max absorption-based light-saturated photosynthetic rate $F_{\mathrm{v}} / F_{\mathrm{m}}$ : maximum photochemical quantum efficiency of photosystem II; $\sigma$ PSII: functional absorption cross-section of photosystem II (10 to $20 \mathrm{~m}^{2}$ photon ${ }^{-1}$ ). These values were obtained at $10 \mathrm{~m}$ depth, values are mean $\pm \mathrm{SD}$

\begin{tabular}{|c|c|c|c|c|c|c|}
\hline \multirow{2}{*}{$\begin{array}{l}\text { Bloom phase } \\
\text { Region }\end{array}$} & \multicolumn{3}{|c|}{$\begin{array}{l}- \text { Pre-bloom }- \\
\left(I_{\text {devel }}<0.15\right)\end{array}$} & \multicolumn{2}{|c|}{$\begin{array}{c}\text { Growth } \\
\left(0.15 \leq I_{\text {devel }}<0.50\right)\end{array}$} & \multirow{2}{*}{$\begin{array}{c}\text { Decline } \\
\left(I_{\text {devel }} \geq 0.5\right) \\
\text { Oyashio }\end{array}$} \\
\hline & Oyashio & WSG & Transition & Oyashio & Transition & \\
\hline \multicolumn{7}{|c|}{ Physical conditions } \\
\hline Temp. & $3.4 \pm 2.1$ & $2.8 \pm 1.1$ & $7.0 \pm 0.7$ & $1.5 \pm 0.9$ & $9.6 \pm 2.6$ & $4.2 \pm 1.6$ \\
\hline MLD & $93 \pm 43$ & $62 \pm 43$ & $195 \pm 92$ & $45 \pm 2$ & $53 \pm 21$ & $29 \pm 16$ \\
\hline ELD & $63 \pm 6$ & $67 \pm 2$ & $62 \pm 10$ & $16 \pm 9$ & $50 \pm 8$ & $23 \pm 12$ \\
\hline $\mathrm{PAR}_{\mathrm{ML}}$ & $2.7 \pm 0.9$ & $7.7 \pm 7.2$ & $2.6 \pm 3.2$ & $3.7 \pm 1.0$ & $8.1 \pm 7.4$ & $7.2 \pm 4.5$ \\
\hline $\mathrm{n}$ & 4 & 2 & 6 & 2 & 6 & 8 \\
\hline \multicolumn{7}{|c|}{ Chemical conditions } \\
\hline$\left[\mathrm{NO}_{3}\right]$ & $19.6 \pm 3.2$ & $20.3 \pm 0.5$ & $12.6 \pm 1.2$ & $12.3 \pm 4.4$ & $9.2 \pm 2.6$ & $6.4 \pm 4.3$ \\
\hline$\left[\mathrm{NH}_{4}\right]$ & $0.1 \pm 0.1$ & $0.2 \pm 0.0$ & $0.2 \pm 0.2$ & $0.1 \pm 0.1$ & $0.3 \pm 0.2$ & $0.3 \pm 0.2$ \\
\hline$\left[\mathrm{Si}(\mathrm{OH})_{4}\right]$ & $37.6 \pm 6.2$ & $39.5 \pm 1.2$ & $24.0 \pm 1.4$ & $27.3 \pm 9.8$ & $18.1 \pm 6.9$ & $11.0 \pm 7.7$ \\
\hline$[\mathrm{D}-\mathrm{Fe}]$ & $0.51 \pm 0.10$ & $0.14 \pm 0.06$ & $0.28 \pm 0.16$ & $0.37 \pm 0.11$ & $0.20 \pm 0.09$ & $0.12 \pm 0.07$ \\
\hline $\mathrm{n}$ & 4 & 2 & 6 & 2 & 6 & 8 \\
\hline $\begin{array}{l}\text { Biological co } \\
{[\text { Chl. a] }}\end{array}$ & $0.45 \pm 0.10$ & $0.43 \pm 0.03$ & $0.62 \pm 0.25$ & $8.26 \pm 3.11$ & $1.00 \pm 0.39$ & $4.18 \pm 3.67$ \\
\hline $\begin{array}{l}\text { Diatom\% } \\
\mathrm{n}\end{array}$ & $\begin{array}{c}12 \pm 6 \\
4\end{array}$ & $\begin{array}{c}14 \pm 4 \\
2\end{array}$ & $\begin{array}{c}17 \pm 7 \\
6\end{array}$ & $\begin{array}{c}93 \pm 1 \\
2\end{array}$ & $\begin{array}{c}17 \pm 24 \\
6\end{array}$ & $\begin{array}{c}66 \pm 22 \\
8\end{array}$ \\
\hline Prim. Prod. & $16 \pm 6$ & $10 \pm 2$ & $25 \pm 22$ & 156 & $51 \pm 42$ & $194 \pm 107$ \\
\hline Assim No. & $34 \pm 7$ & $24 \pm 3$ & $31 \pm 14$ & 26 & $48 \pm 14$ & $83 \pm 36$ \\
\hline Growth rate & $0.20 \pm 0.05$ & $0.14 \pm 0.05$ & $0.22 \pm 0.14$ & 0.55 & $0.37 \pm 0.24$ & $0.46 \pm 0.11$ \\
\hline $\mathrm{n}$ & 3 & 2 & 6 & 1 & 2 & 5 \\
\hline \multicolumn{7}{|c|}{ Photosynthetic parameters } \\
\hline$P_{\text {max }}^{\mathrm{B}}$ & $2.19 \pm 0.16$ & $2.02 \pm 0.20$ & $2.57 \pm 0.80$ & $1.50 \pm 0.38$ & $2.55 \pm 1.01$ & $4.80 \pm 1.76$ \\
\hline$\alpha^{\mathrm{B}}$ & $0.015 \pm 0.002$ & $0.015 \pm 0.001$ & $0.017 \pm 0.003$ & $0.008 \pm 0.001$ & $0.016 \pm 0.005$ & $0.038 \pm 0.017$ \\
\hline$\beta^{\mathrm{B}}$ & $0.5 \pm 0.1$ & $0.3 \pm 0.2$ & $1.2 \pm 1.0$ & $0.9 \pm 0.9$ & $0.9 \pm 0.3$ & $1.6 \pm 0.6$ \\
\hline$E_{\mathrm{k}}$ & $146 \pm 27$ & $135 \pm 8$ & $153 \pm 41$ & $189 \pm 31$ & $171 \pm 74$ & $127 \pm 11$ \\
\hline $\bar{a}^{*}{ }_{\mathrm{ph}}$ & $0.014 \pm 0.003$ & $0.020 \pm 0.003$ & $0.016 \pm 0.002$ & $0.010 \pm 0.001$ & $0.017 \pm 0.003$ & $0.020 \pm 0.011$ \\
\hline$\Phi_{\max }$ & $0.025 \pm 0.005$ & $0.018 \pm 0.002$ & $0.025 \pm 0.005$ & $0.019 \pm 0.003$ & $0.023 \pm 0.010$ & $0.056 \pm 0.036$ \\
\hline$P^{*} \max$ & $3.66 \pm 0.93$ & $2.39 \pm 0.16$ & $3.83 \pm 1.52$ & $3.59 \pm 1.11$ & $3.45 \pm 0.93$ & $7.29 \pm 5.15$ \\
\hline $\mathrm{n}$ & 3 & 2 & 4 & 2 & 3 & 5 \\
\hline$F_{\mathrm{v}} / F_{\mathrm{m}}$ & $0.36 \pm 0.03$ & $0.38 \pm 0.05$ & $0.36 \pm 0.06$ & $0.48 \pm 0.05$ & $0.38 \pm 0.06$ & $0.38 \pm 0.07$ \\
\hline$\sigma_{\mathrm{PSII}}$ & $471 \pm 70$ & $496 \pm 83$ & $503 \pm 51$ & $358 \pm 0$ & $530 \pm 49$ & $509 \pm 78$ \\
\hline $\mathrm{n}$ & 4 & 2 & 6 & 2 & 6 & 8 \\
\hline
\end{tabular}

D-Fe concentrations, which were $60 \%$ lower than in the Oyashio region (Fig. 2f).

During the growth phase of the bloom, the mixed layer became shallower by about $50 \mathrm{~m}$, and the PAR $\mathrm{RL}_{\mathrm{ML}}$ increased from the pre-bloom condition (Table 1). The chl a concentration and the diatom fraction in the Oyashio region increased to about $10 \mu \mathrm{g}^{-1}$ and $90 \%$, respectively, while the increases in the Transition region were relatively small (Fig. $2 g, \mathrm{~h}$ ). The PP and the growth rates of the phytoplankton assemblage in both regions tended to increase from the pre-bloom phase
(Fig. 2i,j), while the assimilation numbers were almost at the same level as the pre-bloom condition (Table 1). The macro- and micronutrient concentrations in the Oyashio region decreased to about $50 \%$ of the initial values in the pre-bloom phase (Fig. 2c,e,f). In the Transition region, the nitrate and silicic acid concentrations gradually decreased during the growth phase, while the decreasing trend in the D-Fe was not observed. The most obvious changes in the physiological parameters in the Oyashio region between the pre-bloom and the growth phases were $F_{\mathrm{v}} / F_{\mathrm{m}}$ and $\sigma_{\mathrm{PSII}}$. The mean 

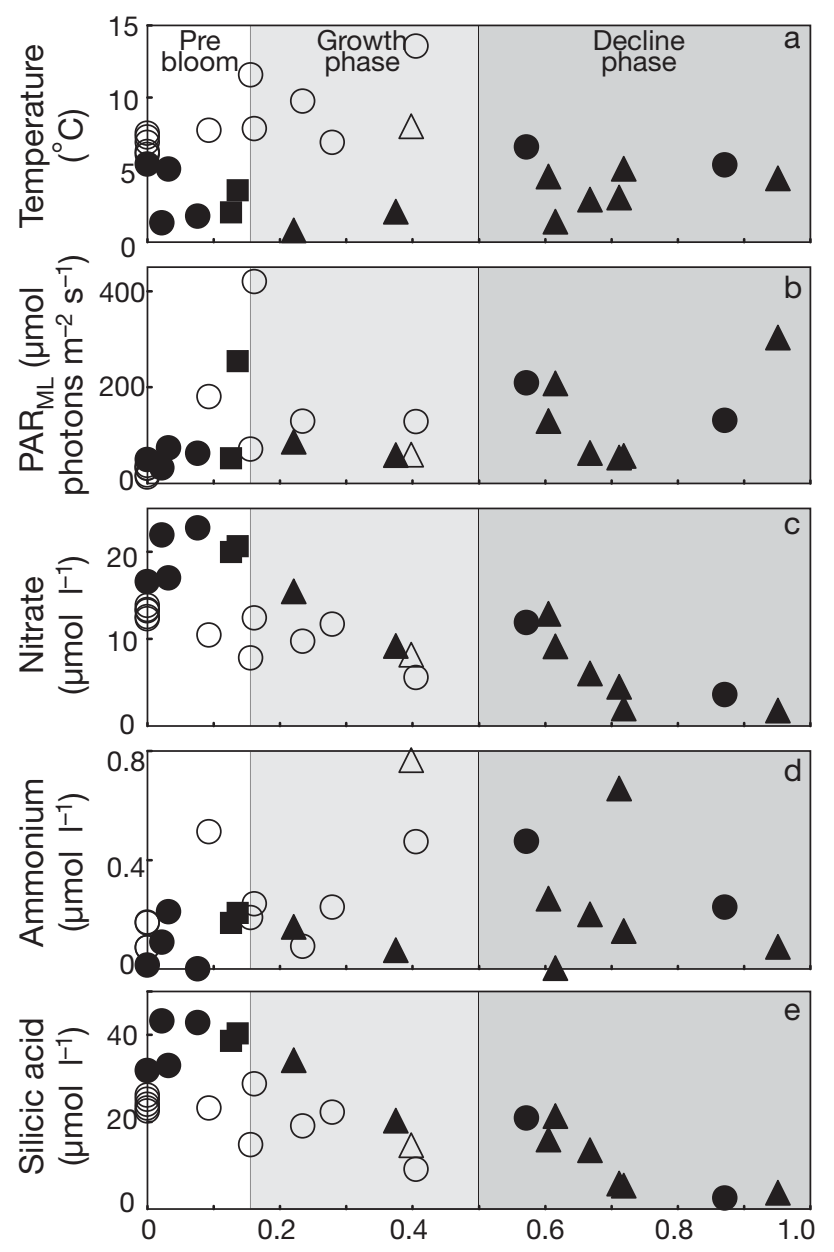

Diatom bloom development index $\left(I_{\text {devel }}\right)$

Fig. 2. Temporal changes in environmental conditions with the development of the spring diatom bloom. (a) Water temperature; (b) daily irradiance flux vertically averaged in the mixed layer ( $\left.\mathrm{PAR}_{\mathrm{ML}}\right)_{i}$ (c) nitrate; (d) ammonium; (e) silicic acid; (f) dissolved iron (data from Nishioka et al. 2007); (g) chl $a_{i}$ (h) fraction of diatoms in the phytoplankton assemblage estimated from CHEMTAX; (i) primary production; (j) growth rate. The spring bloom was divided into 3 phases: pre-bloom, growth (light gray shading) and

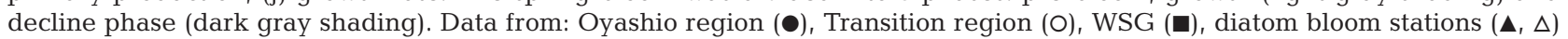

values of $F_{\mathrm{v}} / F_{\mathrm{m}}$ increased from 0.36 to 0.48 , and the $\sigma_{\mathrm{P} \text { - }}$ SII decreased to about $75 \%$ of the values observed in the pre-bloom (Table 1, Fig. 4e). In the Transition region, changes in both parameters were not significant, although high $F_{\mathrm{v}} / F_{\mathrm{m}}$ values were observed at some stations. Despite large changes in the environmental conditions and photosystem II parameters, variability in the other photosynthetic parameters was unapparent. Only an increase in $\beta^{\mathrm{B}}$ and slight decreases in $P_{\text {max }}^{\mathrm{B}}$ $\alpha^{\mathrm{B}}$, and $\bar{a}^{*}{ }_{\mathrm{ph}}$ were observed in the Oyashio region (Table 1, Fig. 4a-c). When the photosynthetic parameters were compared between both regions in the growth phase, the $P^{\mathrm{B}}{ }_{\max }, \alpha^{\mathrm{B}}, \bar{a}^{*}{ }_{\mathrm{ph}}$, and $\sigma_{\mathrm{PSII}}$ were relatively higher in the Transition region than in the Oyashio region, and the $F_{\mathrm{v}} / F_{\mathrm{m}}$ was lower in the Transition region than in the Oyashio region (Table 1).
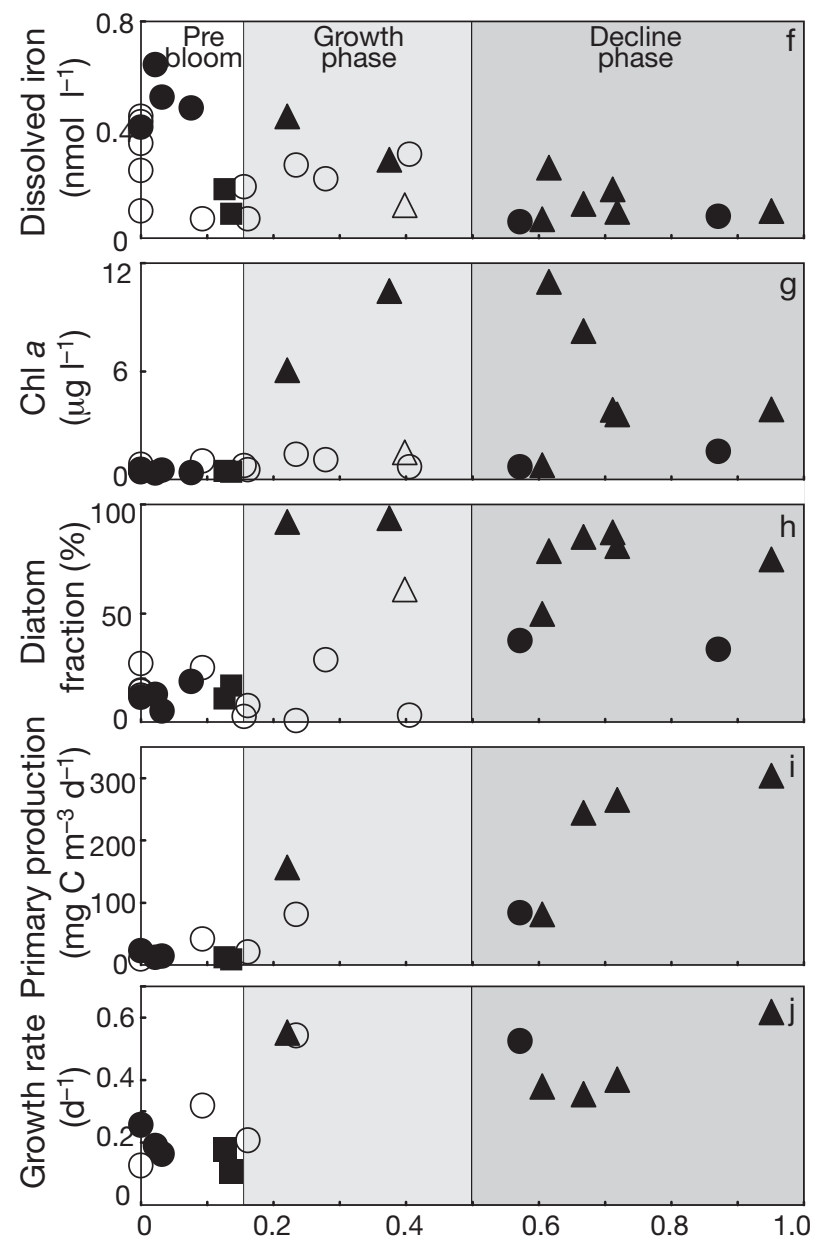

The decline phase of the bloom was only observed in the Oyashio region in this study. The mixed layer became shallower, and the $\mathrm{PAR}_{\mathrm{ML}}$ became higher than in the growth phase (Table 1). The concentrations of nitrate, silicic acid, and D-Fe further decreased to about $10 \%$ of the initial values in the pre-bloom phase (Fig. 2c,e,f). On the other hand, the mean ammonium concentrations in the Oyashio region increased to about 3 times those in the pre-bloom condition (Table 1, Fig. 2d), although they showed large variations among the stations. Chl a concentrations in the Oyashio region decreased with the increase in $I_{\text {devel }}$ except at 2 stations with $I_{\text {devel }}$ of ca. 0.6. Chl a and D-Fe concentrations and $F_{\mathrm{v}} / F_{\mathrm{m}}$ at the 2 stations were low compared to the other stations in the decline phase (Figs. 2f,g \& 4e), despite $I_{\text {devel }}$ being relatively low and 


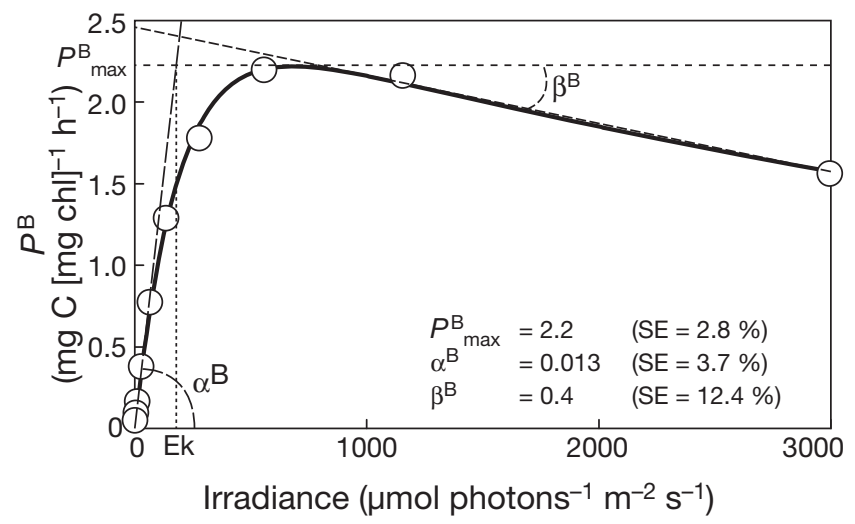

Fig. 3. Example of the photosynthesis-irradiance $(P-E)$ relationship with a fitting curve at Stn. B3 in the Oyashio region. The curve fitting was made to the exponential photoinhibition model using the Levenberg-Marquardt method. $P^{\mathrm{B}}$ : chl a normalized photosynthesis rate; $P_{\text {max }}^{\mathrm{B}}$ light-saturated maximum rate of photosynthesis ( $\left.\mathrm{mg} \mathrm{C}[\mathrm{mg} \mathrm{chl}]^{-1} \mathrm{~h}^{-1}\right) ; \alpha^{\mathrm{B}}$ : light-limited slope of the $P$-E curve $\left(\mathrm{mg} \mathrm{C}[\mathrm{mg} \mathrm{chl}]^{-1} \mathrm{~h}^{-1}\left[\mu \mathrm{mol}\right.\right.$ photons $\mathrm{m}^{-2}$ $\left.\left.\mathrm{s}^{-1}\right]^{-1}\right) ; \quad \beta^{\mathrm{B}}$ : photoinhibition parameter $\left(\mu \mathrm{g} \quad \mathrm{C}\left[\begin{array}{ll}\mathrm{mg} & \mathrm{chl}\end{array}\right]^{-1}\right.$ $\left.\mathrm{h}^{-1}\left[\mu \mathrm{mol} \text { photons } \mathrm{m}^{-2} \mathrm{~s}^{-1}\right]^{-1}\right) ; E_{\mathrm{k}}$ : light-saturation index; SE: standard error for each parameter

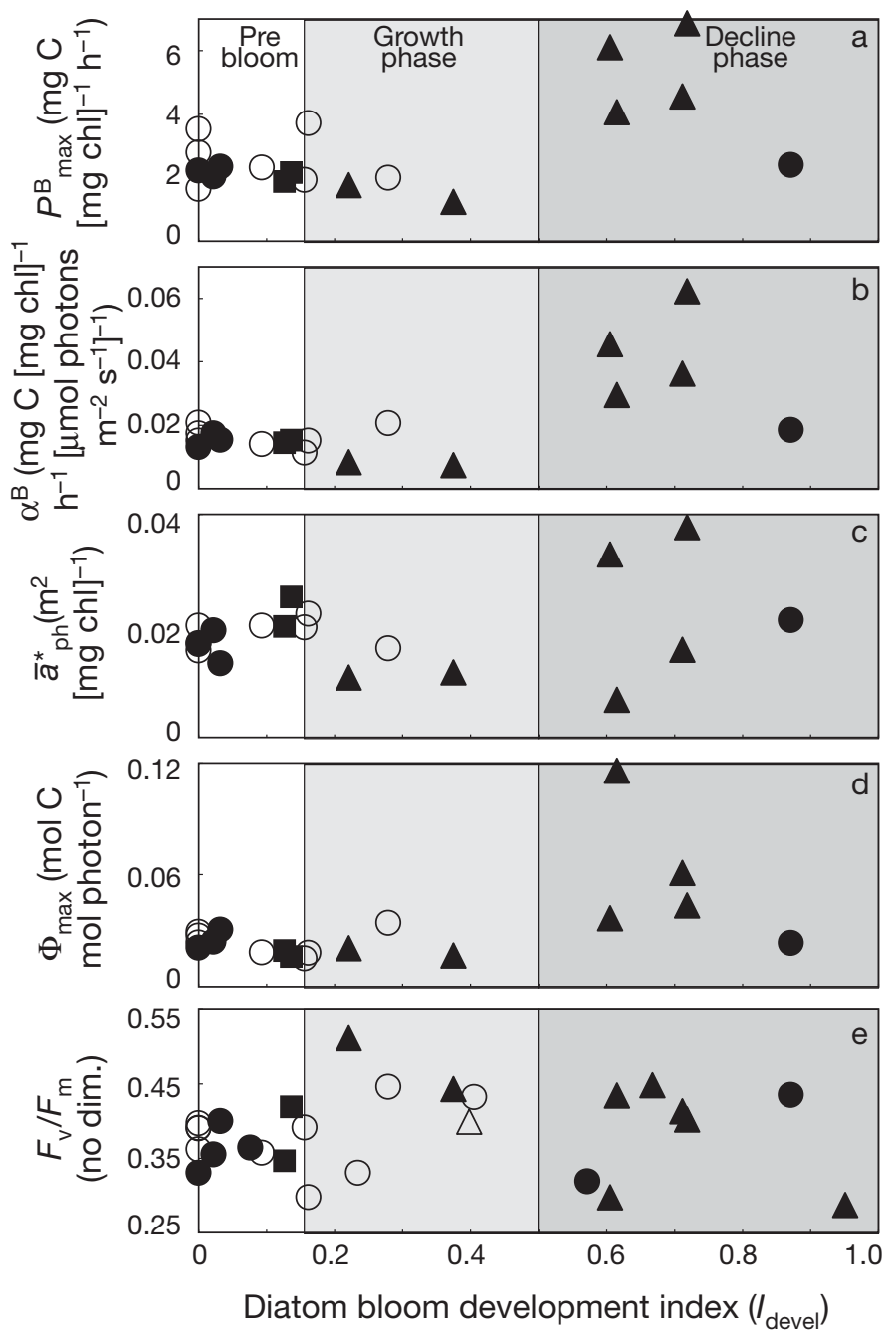

the macronutrients not depleted. The mean diatom fractions in the Oyashio region decreased from the growth phase, but they were still higher than in the pre-bloom condition (Table 1). The PP and assimilation numbers in the Oyashio region tended to increase (Table 1, Fig. 2i), although chl a concentrations and the diatom fractions considerably decreased. Although the algal growth rates showed similar levels as those in the growth phase, they were approximately twice as high as in the pre-bloom (Fig. 2j). The photosynthetic parameters in the decline phase showed more variability than those in the pre-bloom and growth phase (Fig. 4). The mean values of $P_{\text {max }}^{\mathrm{B}} \alpha^{\mathrm{B}}$, and $\Phi_{\max }$ in the Oyashio region in the decline phase were more than 3 times as high as those in the growth phase (Table 1). The mean values of $\beta^{\mathrm{B}}, \bar{a}^{*}{ }_{\mathrm{ph}}, P^{*}{ }_{\max }$, and $\sigma_{\mathrm{PSII}}$ in the Oyashio region also increased from the growth phase (Table 1). On the other hand, the mean $F_{\mathrm{v}} / F_{\mathrm{m}}$ values in the Oyashio region decreased from the growth phase (Table 1), and those in the decline phase were comparable to values found in the pre-bloom phase.

\section{Statistical relationship between environmental conditions and photosynthetic parameters}

We investigated relationships between the physical conditions and algal photosynthetic parameters observed in this study using parametric statistical analysis without any special treatment of the data (Table 2). Water temperature had a significant correlation with $\sigma_{\text {PSII }}$ only. There was no significant correlation between the water temperature and $P^{\mathrm{B}}{ }_{\max }$ in this study, although several previous reports showed positive relationships between them (e.g. Côté \& Platt 1983, Yokouchi et al. 1997, Yoshikawa 2002). MLD and $\mathrm{PAR}_{\mathrm{ML}}$ also did not have any significant relationships with the photosynthetic parameters. On the other hand, ELD had significant negative correlations with $\alpha^{\mathrm{B}}, \Phi_{\text {max }}$, and $P^{*}{ }_{\text {max }}$ indicating that the phytoplankton populations acclimated to the low light conditions associated with the decrease in ELD due to the development of the spring bloom.

Similarly, the relationships between the chemical and algal photosynthetic parameters were also exam-

Fig. 4. Temporal changes of the photosynthetic parameters with the development of the spring diatom bloom. (a) Lightsaturated maximum rate of photosynthesis $\left(P^{\mathrm{B}}{ }_{\max }\right) ;(\mathrm{b})$ lightlimited slope of the photosynthesis-irradiance $(P-E)$ curve $\left(\alpha^{\mathrm{B}}\right)_{\text {; }}(\mathrm{c})$ spectrally weighted chl a specific absorption coefficient of phytoplankton $\left(\bar{a}^{*}{ }_{\mathrm{ph}}\right) ;(\mathrm{d})$ maximum quantum yields of carbon fixation for photosynthesis $\left(\Phi_{\max }\right)_{i}$ (e) maximum photochemical quantum efficiency of phytoplankton photosystem II $\left(F_{\mathrm{v}} / F_{\mathrm{m}}\right)$. Symbols as in Fig. 2 
Table 2. Pearson product-moment correlation coefficients between photosynthetic parameters and environmental conditions. [Diatom]: diatom fraction $\times[\mathrm{chl} a]_{;}$other abbreviations as in Table 1 . Values in bold are significant; ${ }^{*} \mathrm{p}<0.05_{i}^{* *} \mathrm{p}<0.01$

\begin{tabular}{|c|c|c|c|c|c|c|c|c|c|}
\hline & & $P_{\max }^{\mathrm{B}}$ & $\alpha^{\mathrm{B}}$ & $\beta^{\mathrm{B}}$ & $\bar{a}^{*}{ }_{\mathrm{ph}}$ & $\Phi_{\max }$ & $P^{*}{ }_{\max }$ & $F_{\mathrm{v}} / F_{\mathrm{m}}$ & $\sigma_{\mathrm{PSII}}$ \\
\hline \multicolumn{10}{|c|}{ Physical conditions } \\
\hline \multirow[t]{3}{*}{ Temp. } & $\mathrm{r}$ & 0.00 & -0.08 & 0.03 & 0.24 & -0.33 & -0.30 & -0.18 & $0.53^{* *}$ \\
\hline & $\mathrm{p}$ & 0.989 & 0.730 & 0.888 & 0.313 & 0.163 & 0.212 & 0.360 & 0.004 \\
\hline & $\mathrm{n}$ & 19 & 19 & 19 & 19 & 19 & 19 & 28 & 28 \\
\hline \multirow[t]{3}{*}{ MLD } & $\mathrm{r}$ & -0.31 & -0.24 & 0.02 & -0.15 & -0.22 & -0.26 & -0.23 & -0.09 \\
\hline & $\mathrm{p}$ & 0.202 & 0.327 & 0.919 & 0.529 & 0.360 & 0.290 & 0.232 & 0.481 \\
\hline & $\mathrm{n}$ & 19 & 19 & 19 & 19 & 19 & 19 & 28 & 28 \\
\hline \multirow[t]{3}{*}{ ELD } & $\mathrm{r}$ & -0.44 & $-0.49^{*}$ & -0.31 & 0.03 & $-0.53^{*}$ & $-0.48^{*}$ & -0.29 & 0.26 \\
\hline & $\mathrm{p}$ & 0.059 & 0.033 & 0.197 & 0.913 & 0.020 & 0.037 & 0.129 & 0.175 \\
\hline & $\mathrm{n}$ & 19 & 19 & 19 & 19 & 19 & 19 & 28 & 28 \\
\hline \multirow[t]{3}{*}{$\mathrm{PAR}_{\mathrm{ML}}$} & $\mathrm{r}$ & 0.14 & -0.06 & -0.17 & 0.10 & 0.08 & 0.20 & -0.25 & 0.20 \\
\hline & $\mathrm{p}$ & 0.572 & 0.803 & 0.476 & 0.669 & 0.736 & 0.423 & 0.193 & 0.306 \\
\hline & $\mathrm{n}$ & 18 & 18 & 18 & 18 & 18 & 19 & 27 & 27 \\
\hline \multicolumn{10}{|c|}{ Chemical conditions } \\
\hline \multirow[t]{3}{*}[\mathrm{NO}_{3}]{} & $\mathrm{r}$ & $-0.47^{*}$ & $-0.50^{*}$ & -0.34 & -0.18 & -0.34 & -0.28 & -0.13 & -0.26 \\
\hline & $\mathrm{p}$ & 0.042 & 0.030 & 0.157 & 0.458 & 0.155 & 0.245 & 0.499 & 0.188 \\
\hline & $\mathrm{n}$ & 19 & 19 & 19 & 19 & 19 & 19 & 28 & 28 \\
\hline \multirow[t]{3}{*}[\mathrm{NH}_{4}]{} & $\mathrm{r}$ & 0.22 & 0.18 & 0.18 & 0.14 & -0.02 & -0.05 & 0.07 & 0.22 \\
\hline & $\mathrm{p}$ & 0.370 & 0.455 & 0.449 & 0.555 & 0.933 & 0.833 & 0.716 & 0.068 \\
\hline & $\mathrm{n}$ & 19 & 19 & 19 & 19 & 19 & 19 & 28 & 28 \\
\hline \multirow[t]{3}{*}[\mathrm{Si}(\mathrm{OH})_{4}]{} & $\mathrm{r}$ & $-0.53^{*}$ & $-0.56^{*}$ & $-0.47^{*}$ & -0.28 & -0.30 & -0.22 & -0.09 & -0.34 \\
\hline & $\mathrm{p}$ & 0.020 & 0.012 & 0.042 & 0.245 & 0.208 & 0.360 & 0.662 & 0.074 \\
\hline & $\mathrm{n}$ & 19 & 19 & 19 & 19 & 19 & 19 & 28 & 28 \\
\hline \multirow[t]{3}{*}[\mathrm{D}-\mathrm{Fe}]{} & $\mathrm{r}$ & -0.42 & -0.37 & -0.22 & $-0.53^{*}$ & -0.03 & -0.01 & 0.06 & $-0.46^{*}$ \\
\hline & $\mathrm{p}$ & 0.070 & 0.120 & 0.355 & 0.019 & 0.892 & 0.983 & 0.761 & 0.013 \\
\hline & $\mathrm{n}$ & 19 & 19 & 19 & 19 & 19 & 19 & 28 & 28 \\
\hline \multicolumn{10}{|c|}{ Biological conditions } \\
\hline \multirow[t]{3}{*}{ [Chl. a] } & $\mathrm{r}$ & 0.06 & 0.08 & 0.10 & -0.45 & $0.58^{* *}$ & $0.60^{* *}$ & $0.47^{*}$ & $-0.52^{* *}$ \\
\hline & $\mathrm{p}$ & 0.802 & 0.759 & 0.674 & 0.051 & 0.010 & 0.006 & 0.012 & 0.005 \\
\hline & $\mathrm{n}$ & 19 & 19 & 19 & 19 & 19 & 19 & 28 & 28 \\
\hline \multirow[t]{3}{*}{ [Diatom] } & $\mathrm{r}$ & 0.05 & 0.06 & 0.09 & -0.44 & $0.51^{*}$ & $0.54^{*}$ & $0.49^{* *}$ & $-0.55^{* *}$ \\
\hline & $\mathrm{p}$ & 0.846 & 0.806 & 0.708 & 0.059 & 0.026 & 0.017 & 0.009 & 0.002 \\
\hline & $\mathrm{n}$ & 19 & 19 & 19 & 19 & 19 & 19 & 28 & 28 \\
\hline \multirow[t]{3}{*}{$I_{\text {devel }}$} & $\mathrm{r}$ & $0.59^{* *}$ & $0.64^{* *}$ & 0.39 & 0.26 & $0.51^{*}$ & 0.41 & 0.14 & 0.13 \\
\hline & $\mathrm{p}$ & 0.009 & 0.003 & 0.096 & 0.283 & 0.027 & 0.082 & 0.479 & 0.506 \\
\hline & $\mathrm{n}$ & 19 & 19 & 19 & 19 & 19 & 19 & 28 & 28 \\
\hline
\end{tabular}

ined (Table 2). Previous studies (Greene et al. 1991, Platt et al. 1992, Lindley et al. 1995, Lindley \& Barber 1998, Davey \& Geider 2001, Van Oijen et al. 2004, 2005, Marchetti et al. 2006) reported positive relationships between the concentrations of macro- and micronutrients and the photosynthetic parameters, especially under low nutrient conditions. In our study under relatively high nutrient conditions, the concentrations of nitrate and silicic acid had significant negative correlations with $P^{\mathrm{B}}{ }_{\max }$ and $\alpha^{\mathrm{B}}$. In addition, the concentrations of $\mathrm{D}-\mathrm{Fe}$ also had significant negative correlations with $\bar{a}^{*}{ }_{p h}$. However, there was no significant correlation between the ambient nutrient levels and $F_{\mathrm{v}} / F_{\mathrm{m}}$, which is often used as an index of nutrient deficiency for phytoplankton (e.g. Suzuki et al. 2002b).
The result indicates that some of the phytoplankton assemblages were under steady-state growth conditions. Parkhill et al. (2001) showed that $F_{\mathrm{v}} / F_{\mathrm{m}}$ was still high and insensitive to nutrient limitation for algal cultures in steady-state conditions under a wide range of growth rates.

Concerning the relationships between the algal photosynthetic parameters and the other biological elements, chl a concentrations of the phytoplankton assemblage and the diatoms were positively correlated with $\Phi_{\text {max }}, P^{*}{ }_{\text {max }}$ and $F_{\mathrm{v}} / F_{\mathrm{m}}$ (Table 2). Furthermore, significant relationships were found among the chl a concentrations of 4 phytoplankton groups and the photosynthetic parameters: prymnesiophytes and $\sigma_{\text {PSII }}(r=0.46, p<0.05)$, pelagophytes and $\sigma_{\text {PSII }}(r=0.54$, 
$\mathrm{p}<0.01)$, chlorophytes and $\Phi_{\max }(\mathrm{r}=0.83, \mathrm{p}<0.01)$; $\mathrm{P}^{*}{ }_{\max }(\mathrm{r}=0.86, \mathrm{p}<0.01)$, and dinophytes and $\alpha^{\mathrm{B}}(\mathrm{r}=$ $0.51, \mathrm{p}<0.05) ; \Phi_{\max }(\mathrm{r}=0.66, \mathrm{p}<0.01) ; \mathrm{P}^{*}{ }_{\max }(\mathrm{r}=$ $0.56, \mathrm{p}<0.05)$. These results suggest that the group composition of the phytoplankton assemblage significantly affects several photosynthetic parameters. The positive relationship between diatom concentrations and photosynthetic parameters was also confirmed by previous studies (e.g. positive relationships between the diatom fraction, $P^{\mathrm{B}}{ }_{\max }$ and $\alpha^{\mathrm{B}}$; Claustre et al. 1997). $I_{\text {devel }}$ was also positively correlated with $P^{\mathrm{B}}{ }_{\max }$ $\alpha^{\mathrm{B}}$, and $\Phi_{\max }$ (Table 2). The results indicate that the photosynthetic efficiency of the phytoplankton assemblage increased with the development of the diatom bloom. PP and Assim. No. had significant positive correlations with $P^{\mathrm{B}}$ max and $\alpha^{\mathrm{B}}\left(\mathrm{PP}\right.$ and $P^{\mathrm{B}}{ }_{\max }$ $\mathrm{r}=0.66, \mathrm{p}<0.05 ; \mathrm{PP}$ and $\alpha^{\mathrm{B}}, \mathrm{r}=0.71, \mathrm{p}<0.05$; Assim. No. and $\mathrm{P}^{\mathrm{B}}{ }_{\max }, \mathrm{r}=0.88, \mathrm{p}<0.01$; Assim. No. and $\alpha^{\mathrm{B}}$, $\mathrm{r}=0.81, \mathrm{p}<0.01$ ), suggesting that phytoplankton productivity could be well reproduced by the $P-E$ parameters.

As for the relationships among the photosynthetic parameters observed in all regions, our statistical analyses revealed 2 remarkably strong correlations between $P^{\mathrm{B}}{ }_{\text {max }}$ and $\alpha^{\mathrm{B}}$, and between $P^{*}{ }_{\text {max }}$ and $\Phi_{\max }$ (Table 3). These relationships were predominant at the stations where diatoms bloomed (Fig. 5).
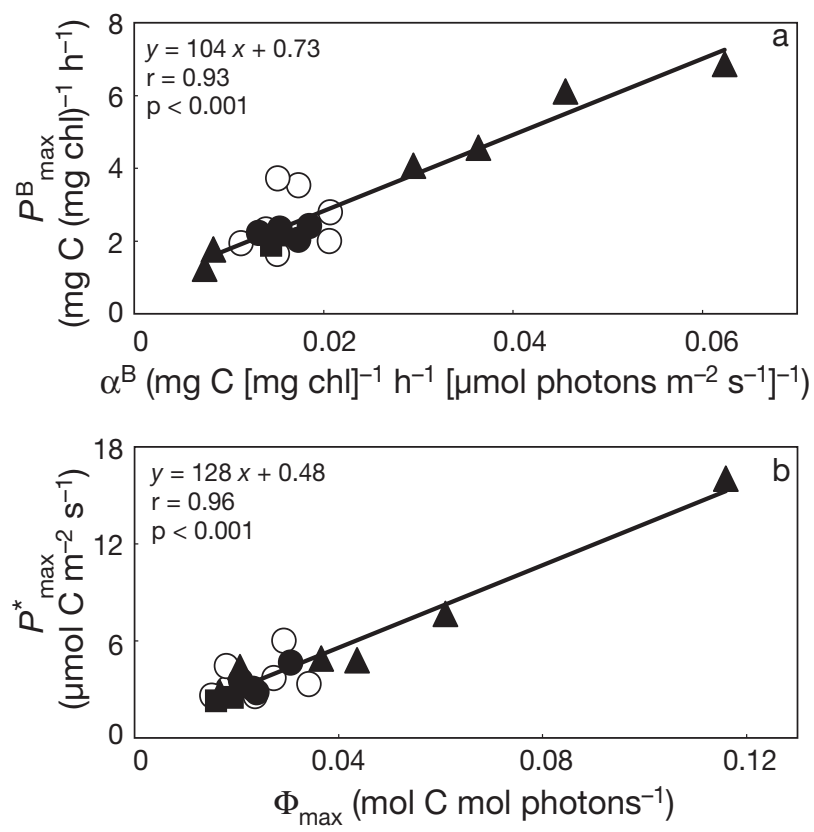

Fig. 5. Relationships among the photosynthetic parameters. (a) Light-saturated maximum rate of photosynthesis $\left(P^{\mathrm{B}}{ }_{\max }\right)$ vs. light-limited slope of the photosynthesis-irradiance $(P-E)$ curve $\left(\alpha^{\mathrm{B}}\right)$; (b) absorption-base light-saturated photosynthetic rates $\left(P^{*}{ }_{\max }\right)$ vs. maximum quantum yields $\left(\Phi_{\max }\right)$. Data from: Oyashio region $(\bullet)$, Transition region $(0)$, WSG (ם), diatom bloom station $(\mathbf{\Lambda})$

\section{DISCUSSION}

Table 3. Pearson product-moment correlation coefficients between photosynthetic parameters. Abbreviations as in Table 1. Values in bold are significant; ${ }^{*} \mathrm{p}<0.05 ;{ }^{* *} \mathrm{p}<0.01$

\begin{tabular}{|c|c|c|c|c|c|c|c|c|}
\hline & & $P_{\max }^{\mathrm{B}}$ & $\alpha^{\mathrm{B}}$ & $\beta^{\mathrm{B}}$ & $\overline{\mathrm{a}}_{\mathrm{ph}}^{*}$ & $\Phi_{\max }$ & $P_{\max }^{*}$ & $F_{\mathrm{v}} / F_{\mathrm{m}}$ \\
\hline$\alpha^{\mathrm{B}}$ & $\begin{array}{l}\mathrm{r} \\
\mathrm{p} \\
\mathrm{n}\end{array}$ & $\begin{array}{c}\mathbf{0 . 9 3}^{* *} \\
<0.001 \\
19\end{array}$ & & & & & & \\
\hline$\beta^{\mathrm{B}}$ & $\begin{array}{l}\mathrm{r} \\
\mathrm{p} \\
\mathrm{n}\end{array}$ & $\begin{array}{c}\mathbf{0 . 5 3}^{*} \\
0.020 \\
19\end{array}$ & $\begin{array}{c}0.43 \\
0.064 \\
19\end{array}$ & & & & & \\
\hline $\bar{a}^{*}{ }_{\mathrm{ph}}$ & $\begin{array}{l}\mathrm{r} \\
\mathrm{p} \\
\mathrm{n}\end{array}$ & $\begin{array}{c}\mathbf{0 . 6 2}{ }^{* *} \\
0.005 \\
19\end{array}$ & $\begin{array}{c}\mathbf{0 . 6 5}^{\text {** }} \\
0.003 \\
19\end{array}$ & $\begin{array}{c}0.08 \\
0.749 \\
19\end{array}$ & & & & \\
\hline$\Phi_{\max }$ & $\begin{array}{l}\mathrm{r} \\
\mathrm{p} \\
\mathrm{n}\end{array}$ & $\begin{array}{c}\mathbf{0 . 4 8}^{*} \\
0.037 \\
19\end{array}$ & $\begin{array}{c}\mathbf{0 . 4 9}^{*} \\
0.034 \\
19\end{array}$ & $\begin{array}{c}0.41 \\
0.082 \\
19\end{array}$ & $\begin{array}{c}-0.26 \\
0.287 \\
19\end{array}$ & & & \\
\hline$P^{*} \max$ & $\begin{array}{l}\mathrm{r} \\
\mathrm{p} \\
\mathrm{n}\end{array}$ & $\begin{array}{c}0.44 \\
0.058 \\
19\end{array}$ & $\begin{array}{c}0.35 \\
0.136 \\
19\end{array}$ & $\begin{array}{c}0.44 \\
0.061 \\
19\end{array}$ & $\begin{array}{c}-0.36 \\
0.134 \\
19\end{array}$ & $\begin{array}{c}\mathbf{0 . 9 6}^{* *} \\
<0.001 \\
19\end{array}$ & & \\
\hline$F_{\mathrm{v}} / F_{\mathrm{m}}$ & $\begin{array}{l}\mathrm{r} \\
\mathrm{p} \\
\mathrm{n}\end{array}$ & $\begin{array}{c}-0.30 \\
0.212 \\
19\end{array}$ & $\begin{array}{c}-0.14 \\
0.557 \\
19\end{array}$ & $\begin{array}{c}0.04 \\
0.855 \\
19\end{array}$ & $\begin{array}{c}-0.45 \\
0.053 \\
19\end{array}$ & $\begin{array}{c}0.20 \\
0.419 \\
19\end{array}$ & $\begin{array}{c}0.20 \\
0.419 \\
19\end{array}$ & \\
\hline$\sigma_{\mathrm{PSII}}$ & $\begin{array}{l}\mathrm{r} \\
\mathrm{p} \\
\mathrm{n}\end{array}$ & $\begin{array}{c}0.34 \\
0.157 \\
19\end{array}$ & $\begin{array}{c}0.27 \\
0.264 \\
19\end{array}$ & $\begin{array}{c}0.19 \\
0.425 \\
19\end{array}$ & $\begin{array}{c}\mathbf{0 . 5 4}^{*} \\
0.018 \\
19\end{array}$ & $\begin{array}{c}-0.17 \\
0.497 \\
19\end{array}$ & $\begin{array}{c}-0.17 \\
0.497 \\
19\end{array}$ & $\begin{array}{c}-0.35 \\
0.065 \\
28\end{array}$ \\
\hline
\end{tabular}

Recently, the phytoplankton physiological mechanisms underlying the covariation of $P^{\mathrm{B}}{ }_{\text {max }}$ and $\alpha^{\mathrm{B}}$ (i.e. $E_{\mathrm{k}}$-independent variability) were reviewed by Behrenfeld et al. (2004). They divided the photosynthetic process into 2 groups of physiological processes, one was the photosynthetic electron transfer (PET) process (e.g. light harvesting and reductant production), the other was downstream processes of the PET (e.g. carbon fixation and nitrogen assimilation), and showed the importance of the latter processes for the $E_{\mathrm{k}}$ independent variability. They suggested that changes in the distribution ratio of the reductants produced by PET among 3 downstream processes (carbon fixation, nitrogen assimilation, and ATP synthesis) affected both $P_{\text {max }}^{\mathrm{B}}$ and $\alpha^{\mathrm{B}}$ (Fig. 6 in Behrenfeld et al. 2004). When the growth rate of phytoplankton decreases due to nutrient limitation, most reductants are distributed to the ATP synthesis for main- 
taining cell metabolism, and a small proportion is distributed to carbon fixation and nitrogen assimilation. As a result, both $P^{\mathrm{B}}{ }_{\max }$ and $\alpha^{\mathrm{B}}$ can decrease with a decrease in the growth rate.

We considered what processes controlled the $E_{\mathrm{k}}$ independent variability observed in this study. $\bar{a}^{*}{ }_{p h}$ is a proxy of the light-harvesting efficiency in the PET processes and changes with the light intensity, the accessory pigment complement, cell size, and intracellular pigment concentration (e.g. Geider \& MacIntyre 2002). In this study, $\bar{a}^{*}{ }_{\mathrm{ph}}$ was significantly correlated with both $P^{\mathrm{B}}$ max and $\alpha^{\mathrm{B}}$ (Table 3). To take account of the effects of the change in $\bar{a}^{*}{ }_{p h}$ on the $E_{\mathrm{k}}$-independent variability, we examined the relationship between absorption-based light-saturated photosynthetic rates $\left(P^{*}{ }_{\max }=0.0231 P^{\mathrm{B}}{ }_{\max } / \bar{a}^{*}{ }_{\mathrm{ph}}\right)$ and maximum quantum yields $\left(\Phi_{\max }=0.0231 \alpha^{\mathrm{B}} / \bar{a}^{*}{ }_{\mathrm{ph}}\right)$. There was still a significant positive correlation between $P^{*}$ max and $\Phi_{\max }$ (Fig. 5b, Table 3), although the relative positions of each station in the graph of $P^{*}$ max and $\Phi_{\max }$ (Fig. 5b) changed from those in the graph of $P^{\mathrm{B}}{ }_{\max }$ and $\alpha^{\mathrm{B}}$ (Fig. 5a). The slopes of the regression lines (i.e. $E_{\mathrm{k}}$ ) in Fig. 5a and 5b were similar to each other $\left(P^{\mathrm{B}}\right.$ max and $\alpha^{\mathrm{B}}$ : $104 \mu \mathrm{mol}$ photons $\mathrm{m}^{-2} \mathrm{~s}^{-1} ; P^{*}{ }_{\max }$ and $\Phi_{\max }: 128 \mu \mathrm{mol}$ photons $\mathrm{m}^{-2} \mathrm{~s}^{-1}$ ). These results indicated that the changes in $\bar{a}^{*}{ }_{\mathrm{ph}}$ simultaneously affected the values of both $P_{\text {max }}^{\mathrm{B}}$ and $\alpha^{\mathrm{B}}$. Therefore, the changes in the lightharvesting efficiency did not contribute to the $E_{\mathrm{k}}$-independent variability in this study.

The $P-E$ parameters measured (e.g. $P^{\mathrm{B}}$ max and $\alpha^{\mathrm{B}}$ ) by the ${ }^{13} \mathrm{C}$ technique include the effects of both processes related to PET and the downstream processes of PET; on the other hand, the parameters measured by FRR fluorometry (i.e. $F_{\mathrm{v}} / F_{\mathrm{m}}$ and $\sigma_{\mathrm{PSII}}$ ) are solely related to the PET processes. Comparing their temporal changes, $P^{\mathrm{B}}$ max and $\alpha^{\mathrm{B}}$ were constant from the pre-bloom to the growth phases and thereafter increased, while relatively higher $F_{\mathrm{v}} / F_{\mathrm{m}}$ ratios were observed in the growth phase of the bloom (Fig. 4a,b,e). The different trends indicated that PET processes did not play important roles in the $E_{\mathrm{k}}$-independent variability, and the downstream processes of PET could be more important to the changes in $P^{\mathrm{B}}$ max and $\alpha^{\mathrm{B}}$.

The downstream processes of PET are regulated by temperature, which influences the activity of their enzymes such as RUBISCO, and the temperature dependency is different among phylotypes of phytoplankton (e.g. Raven \& Geider 1988, Davison 1991). We did not find any significant relationships among water temperature, $P_{\text {max }}^{\mathrm{B}}$ and $\alpha^{\mathrm{B}}$ from the statistical analyses using data from all stations as discussed above. However, if we focus only on the diatom bloom stations, $P^{\mathrm{B}}{ }_{\text {max }}$ and $\alpha^{\mathrm{B}}$ were significantly correlated with water temperature and increased 5 -fold along with the increase in water temperature from 0.8 to $5.1^{\circ} \mathrm{C}$ (Fig. 6a,b). Such a
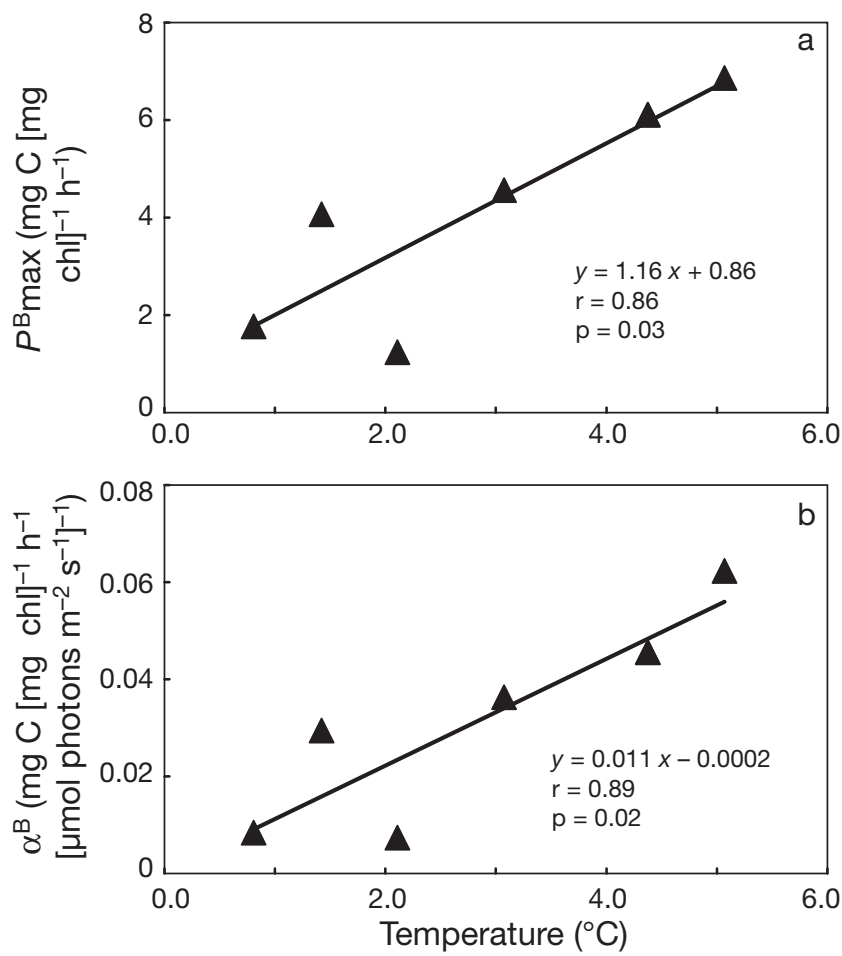

Fig. 6. Relationships between the water temperature and the photosynthetic parameters at the diatom bloom station. (a) light-saturated maximum rate of photosynthesis $\left(P^{\mathrm{B}}{ }_{\max }\right)$; (b) light-limited slope of the photosynthesis-irradiance $(P-E)$ curve $\left(\alpha^{\mathrm{B}}\right)$

positive relationship between $P^{\mathrm{B}}{ }_{\max }$ and water temperature is consistent with previous studies (e.g. Côté \& Platt 1983, Yokouchi et al. 1997, Yoshikawa 2002). Thus, the downstream processes of PET might play a role in the $E_{\mathrm{k}}$-independent variability observed in our study. However, the increments of $P^{\mathrm{B}}$ max and $\alpha^{\mathrm{B}}$ were higher compared to the temperature dependency of enzymes reported previously (e.g. activity of RUBISCO increases 2- to 3 -fold with a $10^{\circ} \mathrm{C}$ increase: Raven \& Geider 1988). The large increase in $P^{\mathrm{B}}{ }_{\max }$ and $\alpha^{\mathrm{B}}$ was probably caused by not only temperature but also by other environmental factors. At the bloom stations, the dominant phytoplankton species were mostly common and mainly consisted of the neritic chain-forming diatoms Thalassiosira nordenskioeldii, Chaetoceros debilis, C. socialis, and Fragilariopsis oceanica. These results suggest that the species composition did not seriously affect the $E_{\mathrm{k}}$-independent variability.

The downstream processes of PET are also influenced by nutrient concentrations due to the substrate dependency of the enzymes (e.g. nitrate dependency of the nitrate reductase in the nitrogen assimilation process). There was also no significant positive relationship among the ambient concentrations of macroand micronutrients, $P^{\mathrm{B}}{ }_{\max }$, and $\alpha^{\mathrm{B}}$ when analyzed for the diatom bloom stations only and for all stations 
combined. This is likely because sufficient amounts of the nutrients remained in the seawater for the phytoplankton.

We also considered the changes in the distribution ratio of reductants between the 2 downstream processes of PET, that is, carbon fixation and nitrogen assimilation. If the requirement of reductants in nitrogen assimilation processes decreases with utilization of the reduced form of nitrogen (ammonium) instead of the oxidized nitrogen (nitrate), and the excess reductants are utilized in carbon fixation, the carbon fixation rate and the $P-E$ parameters will increase. In the Oyashio region, several high concentrations of ammonium were observed in the decline phase (Fig. 2d, Table 1). On the other hand, nitrate concentrations decreased with the development of the bloom. As a result, the relative consumption ratio of ammonium to nitrate probably increased with the bloom development. Thompson et al. (1989) showed no significant advantage of ammonium uptake for the algal growth rate and carbon fixation at low photon flux density $\left(<29 \mu \mathrm{mol}\right.$ photons $\left.\mathrm{m}^{-2} \mathrm{~s}^{-1}\right)$. However, at a high photon flux density ( $>29 \mathrm{\mu mol}$ photons $\mathrm{m}^{-2} \mathrm{~s}^{-1}$ ), the ammonium uptake possessed significant advantages both for the growth rate ( $8 \%$ larger than nitrate uptake) and carbon fixation (21\% higher than nitrate uptake) In this study, the daily averaged photon fluxes in the mixed layer during the growth and decline phases of the bloom became high (63 to $354 \mu \mathrm{mol}$ photons $\mathrm{m}^{-2} \mathrm{~s}^{-1}$ ). We speculate that the effective use of reductants in carbon fixation by saving the requirement of the reductant in nitrogen assimilation with uptake of ammonium might contribute to the $E_{\mathrm{k}}$-independent variability.

Diurnal variations in $P^{\mathrm{B}}$ max and $\alpha^{\mathrm{B}}$ have been reported in the various groups of phytoplankton (e.g. Harding et al. 1982, Harrison \& Platt 1986, Erga \& Skjoldal 1990, Behrenfeld et al. 2004, 2008). In this study, we investigated the time series of $P^{\mathrm{B}}{ }_{\max }$ and $\alpha^{\mathrm{B}}$, which were obtained at various times of the day (0:00-06:00 h: 6 samples; 06:00-12:00 h: 6 samples; 12:00-18:00 h: 4 samples; 18:00-24:00 h: 3 samples), however, such diurnal variation in the photosynthetic parameters was not observed (data not shown).

In this study, we proposed a new index for the development of diatom bloom. Since the diatom bloom index, $I_{\text {devel }}$, is based on in situ nutrient levels in the mixed layer, $I_{\text {devel }}$ is affected by the supply and dilution of silicic acid associated with advection and/or mixing. $I_{\text {devel }}$ decreases with the supply of silicic acid via the physical movement of the water mass (i.e. turning back the spring bloom clock). However, here diatoms are allowed to bloom using the new silicon. The regeneration of silicon within the mixed layer also affects this index. Since the water temperature in this study was low enough (mean water temperature at $10 \mathrm{~m}$ was $5.5^{\circ} \mathrm{C}$ ) and the elapsed time of the bloom observed was short enough (about $1 \mathrm{mo}$ ), the effect of the regeneration of silicon on $I_{\text {devel }}$ is considered to be negligible (e.g. Tréguer et al. 1989, Bidle et al. 2003, Brzezinski et al. 2003). $I_{\text {devel }}$ is considered to be an excellent indicator for estimating the timing of the spring bloom in the Oyashio region. In the WSG, minimal temporal changes in $I_{\text {devel }}$ were observed, coinciding with the lack of diatom blooms. On the other hand, the calculation of $I_{\text {devel }}$ may contain some errors in the Transition region, where small-scale diatom blooms and active horizontal mixing occurred.

Overall, our study clearly showed that $P^{\mathrm{B}}$ max and $\alpha^{\mathrm{B}}$ co-varied in the western subarctic Pacific during the spring bloom period. Water temperature significantly affected the co-variations in $P^{\mathrm{B}}{ }_{\max }$ and $\alpha^{\mathrm{B}}$, while the concentrations of nitrate, silicic acid, and D-Fe did not correlate with the changes in $P_{\text {max }}^{\mathrm{B}}$ and $\alpha^{\mathrm{B}}$. The temperature dependency of $P^{\mathrm{B}}{ }_{\max }$ and $\alpha^{\mathrm{B}}$ suggests that the covariations in $P^{\mathrm{B}}$ max and $\alpha^{\mathrm{B}}$ were probably derived from the downstream processes of PET. Furthermore, the increment of ammonium concentration in the latter half of the bloom could influence the $E_{\mathrm{k}}$-independent variability by saving reductants for nitrogen assimilation. Most marine ecosystem models do not include the covariations in $P_{\text {max }}^{\mathrm{B}}$ and $\alpha^{\mathrm{B}}$, except for some models for the mesoscale iron fertilization experiments which explicitly include the $E_{\mathrm{k}}$-independent variability (Chai et al. 2002, 2007, Fujii et al. 2005, Yoshie et al. 2005). This study suggests that covariations in $P^{\mathrm{B}}{ }_{\max }$ and $\alpha^{\mathrm{B}}$ with reference to changes in environmental factors such as water temperature should be taken into account in ecosystem models investigating the dynamics and control mechanisms of marine ecosystems during spring diatom blooms. Also, it is clearly demonstrated that we need further studies on the factors influencing the phytoplankton photosynthetic physiology in order to understand the mechanisms of marine ecosystem dynamics and to enable realistic models that reproduce ecosystem dynamics during spring diatom blooms.

Acknowledgements. We thank the captain and crew of the RV 'Wakataka Maru' during 2 cruises in the Study for Plankton and Iron dynamics in the Northwestern Subarctic Pacific (SPINUP) project. We are also grateful to M. Nakamachi and $\mathrm{T}$. Ono for measurements of concentrations of the macro nutrients and dissolved inorganic carbon. We also thank Y. Yamanaka, S. Ito, and K. Takahashi for their fruitful discussions and helpful comments. This study was supported in part by the 21st Century COE Program funded by the Ministry of Education, Culture, Sports, Science, and Technology of Japan (MEXT), in part by the scientific program of the Fisheries Research Agency (FRA). This study was partially supported by grants in-aid for scientific research from MEXT (no. 15681001) and the Japan Society for the Promotion of Science 
(JSPS; no. 19510001), the Steel Industry Foundation for the Advancement of Environmental Protection Technology, and the Core Research for Evolutional Science and Technology (CREST) from the Japan Science and Technology Agency (JST). The study was also supported by a grant-in-aid for the Global COE Program from MEXT and JSPS.

\section{LITERATURE CITED}

Behrenfeld MJ, Prasil O, Babin M, Bruyant F (2004) In search of a physiological basis for covariations in light-limited and light-saturated photosynthesis. J Phycol 40:4-25

Behrenfeld MJ, Halsey KH, Milligan AJ (2008) Evolved physiological responses of phytoplankton to their integrated growth environment. Philos Trans R Soc B Biol Sci 363: $2687-2703$

Bidle KD, Brzezinski MA, Long RA, Jones JL, Azam F (2003) Diminished efficiency in the oceanic silica pump caused by bacteria-mediated silica dissolution. Limnol Oceanogr 48:1855-1868

Brzezinski MA, Jones JL, Bidle KD, Azam F (2003) The balance between silica production and silica dissolution in the sea: insights from Monterey Bay, California, applied to the global data set. Limnol Oceanogr 48:1846-1854

Chai F, Dugdale RC, Peng TH, Wilkerson FP, Barber RT (2002) One-dimensional ecosystem model of the equatorial Pacific upwelling system. I. model development and silicon and nitrogen cycle. Deep-Sea Res II 49: 2713-2745

Chai F, Jiang MS, Chao Y, Dugdale RC, Chavez F, Barber RT (2007) Modeling responses of diatom productivity and biogenic silica export to iron enrichment in the equatorial Pacific Ocean. Global Biogeochem Cycles 21:GB3S90. doi:10.1029/2006GB002804

Claustre H, Moline MA, Prézelin BB (1997) Sources of variability in the column photosynthetic cross section for Antarctic coastal waters. J Geophys Res 102(C11): 25047-25060

Cleveland JS, Weidemann AD (1993) Quantifying absorption by aquatic particles: a multiple scattering correction for glass-fiber filters. Limnol Oceanogr 38:1321-1327

Côté B, Platt T (1983) Day-to-day variations in the springsummer photosynthetic parameters of coastal marine phytoplankton. Limnol Oceanogr 28:320-344

> Davey M, Geider RJ (2001) Impact of iron limitation on the photosynthetic apparatus of the diatom Chaetoceros muelleri (Bacillariophyceae). J Phycol 37:987-1000

Davison IR (1991) Environmental effects on algal photosynthesis: temperature. J Phycol 27:2-8

Erga SR, Skjoldal HR (1990) Diel variations in photosynthetic activity of summer phytoplankton in Lindåspollene, western Norway. Mar Ecol Prog Ser 65:73-85

Falkowski PG, Raven J (2007) Photosynthesis in continuous light. In: Falkowski PG, Raven J (eds) Aquatic photosynthesis, 2nd edn. Princeton University Press, Princeton, NJ, p 237-277

Fasham MJR, Ducklow HW, McKelvie SM (1990) A nitrogenbased model of plankton dynamics in the oceanic mixed layer. J Mar Res 48:591-639

Flynn KJ (2001) A mechanistic model for describing dynamic multi-nutrient, light, temperature interactions in phytoplankton. J Plankton Res 23:977-997

Fujii M, Yoshie N, Yamanaka Y, Chai F (2005) Simulated biogeochemical responses to iron enrichments in three high nutrient, low chlorophyll (HNLC) regions. Prog Oceanogr $64: 307-324$
Furuya K, Hasegawa O, Yoshikawa T, Taguchi S (1998) Photosynthesis-irradiance relationship of phytoplankton and primary production in the vicinity of Kuroshio warm core ring in spring. J Oceanogr 54:545-552

Geider RJ, MacIntyre HL (2002) Physiology and biochemistry of photosynthesis and algal carbon acquisition. In: Williams PJ, Thomas DN, Reynolds CS (eds) Phytoplankton productivity: carbon assimilation in marine and freshwater ecosystems, Blackwell Science, Oxford, p 44-77

Geider RJ, MacIntyre HL, Kana TM (1998) A dynamic regulatory model of phytoplanktonic acclimation to light, nutrients, and temperature. Limnol Oceanogr 43:679-694

Greene RM, Geider RJ, Falkowski P (1991) Effect of iron limitation on photosynthesis in a marine diatom. Limnol Oceanogr 36:1772-1782

> Hama T, Miyazaki Y, Ogawa Y, Iwakuma T, Takahashi M, Otsuki A, Ichimura S (1983) Measurement of photosynthetic production of a marine phytoplankton population using a stable ${ }^{13} \mathrm{C}$ isotope. Mar Biol 73:31-36

> Harding LW, Prézelin BB, Sweeney BM, Cox JL (1982) Diel oscillations of the photosynthesis-irradiance (P-I) relationship in natural assemblages of phytoplankton. Mar Biol 67:167-178

Harrison WG, Platt T (1986) Photosynthesis-irradiance relationships in polar and temperate phytoplankton populations. Polar Biol 5:153-164

Kawai H (1972) Hydrography of the Kuroshio Extension. In: Stommel H, Yoshida K (eds) Kuroshio: its physical aspects. University of Tokyo Press, Tokyo, p 235-352

Kishino M, Takahashi M, Okami N, Ichimura S (1985) Estimation of the spectral absorption coefficients of phytoplankton in the sea. Bull Mar Sci 37:634-642

Knap A, Michaels A, Close A, Ducklow HW, Dickson AG (eds) (1996) Protocols for the Joint Global Ocean Flux Study (JGOFS) core measurements. JGOFS Rep No. 19, Reprint of the IOC manuals and guides No. 29, UNESCO, Bergen, Norway

> Kolber ZS, Prasil O, Falkowski PG (1998) Measurements of variable chlorophyll fluorescence using fast repetition rate techniques: defining methodology and experimental protocols. Biochim Biophys Acta 1367:88-106

Kuroda H, Kishi MJ (2004) A data assimilation technique applied to estimate parameters for the NEMURO marine ecosystem model. Ecol Model 172:69-85

Laney SR, Letelier RM (2008) Artifacts in measurements of chlorophyll fluorescence transients, with specific application to fast repetition rate fluorometry. Limnol Oceanogr Methods 6:40-50

Limsakul A, Saino T, Goes JI, Midorikawa T (2002) Seasonal variability in the lower trophic level environments of the western subtropical Pacific and Oyashio waters: a retrospective study. Deep-Sea Res II 49:5487-5512

> Lindley ST, Barber RT (1998) Phytoplankton response to natural and artificial iron addition. Deep-Sea Res II 45:1135-1150

Lindley S, Bidigare RR, Barber RT (1995) Phytoplankton photosynthesis parameters along $140 \mathrm{~W}$ in the equatorial Pacific. Deep-Sea Res II 42:441-463

Mackey MD, Mackey DJ, Higgins HW, Wright SW (1996) CHEMTAX: a program for estimating class abundances from chemical markers: application to HPLC measurements of phytoplankton. Mar Ecol Prog Ser 144:265-283

> Marchetti A, Sherry ND, Juneau P, Strzepek RF, Harrison PJ (2006) Phytoplankton processes during a mesoscale iron enrichment in the NE subarctic Pacific. III. Primary productivity. Deep-Sea Res II 53:2131-2151

> Moline MA, Schofield O, Boucher NP (1998) Photosynthetic parameters and empirical modelling of primary produc- 
tion: a case study on the Antarctic Peninsula shelf. Antarct Sci 10:45-54

Nielsen E, Jørgensen EG (1968) The adaptation of plankton algae. I. General part. Physiol Plant 21:401-413

Nishioka J, Ono T, Saito H, Nakatsuka T and others (2007) Iron supply to the western subarctic Pacific: importance of iron export from the Sea of Okhotsk. J Geophys Res Oceans 112:C10012. doi:10.1029/2006JC004055

Obata H, Karatani H, Nakayama E (1993) Automated determination of iron in seawater by chelating resin concentration and chemiluminescence detection. Anal Chem 65: 1524-1528

Parkhill JP, Maillet G, Cullen J (2001) Fluorescence-based maximal quantum yield for PSII as a diagnostic of nutrient stress. J Phycol 37:517-529

Platt T, Jassby AD (1976) The relationship between photosynthesis and light for natural assemblages of coastal marine phytoplankton. J Phycol 12:421-430

Platt T, Gallegos CL, Harrison WG (1980) Photoinhibition of photosynthesis in natural assemblages of marine phytoplankton. J Mar Res 38:687-701

Platt T, Sathyendranath S, Ulloa O, Harrison WG, Hoepffner N, Goes J (1992) Nutrient control of phytoplankton photosynthesis in the Western North Atlantic. Nature 356:229-231

Raven J, Geider RJ (1988) Temperature and algal growth. New Phytol 110:441-461

Saito H, Tsuda A (2003) Influence of light intensity on diatom physiology and nutrient dynamics in the Oyashio region. Prog Oceanogr 57:251-263

Saito H, Kasai H, Kashiwai M, Kawasaki Y, Kono T, Taguchi S, Tsuda A (1998) General description of seasonal variations of nutrients, chlorophyll a, and netplankton biomass along the A-line transect, western subarctic Pacific, from 1990 to 1994. Bull Hokkaido Natl Fish Res Inst 62:1-62

Saito H, Tsuda A, Kasai H (2002) Nutrient and plankton dynamics in the Oyashio region of the western subarctic Pacific Ocean. Deep-Sea Res II 49:5463-5486

Smetacek V (1999) Diatoms and the ocean carbon cycle. Protist 150:25-32

Suzuki K, Minami C, Liu H, Saino T (2002a) Temporal and spatial patterns of chemotaxonomic algal pigments in the subarctic Pacific and the Bering Sea during the early summer of 1999. Deep-Sea Res II 49:5685-5704

Suzuki K, Liu H, Saino T, Obata H and others (2002b) East-west gradients in the photosynthetic potential of phytoplankton and iron concentration in the subarctic Pacific Ocean during early summer. Limnol Oceanogr 47:1581-1594

Suzuki K, Hinuma A, Saito H, Kiyosawa H, Liu H, Saino T, Tsuda A (2005) Responses of phytoplankton and heterotrophic bacteria in the northwest subarctic Pacific to in situ iron fertilization as estimated by HPLC pigment analysis and flow cytometry. Prog Oceanogr 64:167-187

Editorial responsibility: Alain Vezina,

Dartmouth, Canada
Taniguchi A (1999) Differences in the structure of the lower trophic levels of pelagic ecosystems in the eastern and western subarctic Pacific. Prog Oceanogr 43:289-315

Tassan S, Ferrari GM (1995) An alternative approach to absorption measurements of aquatic particles retained on filters. Limnol Oceanogr 40:1358-1368

Thompson PA, Levasseur ME, Harrison PJ (1989) Light limited growth on ammonium vs. nitrate: What is the advantage for marine phytoplankton? Limnol Oceanogr 34:1014-1024

> Tréguer P, Kamatani A, Gueneley S, Quéguiner B (1989) Kinetics of dissolution of Antarctic diatom frustules and the biogeochemical cycles of silicon in the Southern Ocean. Polar Biol 9:397-403

- Van Oijen T, Van Leeuwe MA, Gieskes WWC, de Baar HJW (2004) Effects of iron limitation on photosynthesis and carbohydrate metabolism in the Antarctic diatom Chaetoceros brevis (Bacillariophyceae). Eur J Phycol 39: 161-171

> Van Oijen T, Veldhuis MJW, Gorbunov MY, Nishioka J, Van Leeuwe MA, de Baar HJW (2005) Enhanced carbohydrate production by Southern Ocean phytoplankton in response to in situ iron fertilization. Mar Chem 93:33-52

Yamanaka Y, Yoshie N, Fujii M, Aita MN, Kishi MJ (2004) An ecosystem model coupled with nitrogen-silicon-carbon cycles applied to station A7 in the Northwestern Pacific. J Oceanogr 60:227-241

Yasuda I (2003) Hydrographic structure and variability in the Kuroshio-Oyashio transition area. J Oceanogr 59:389-402

Yokouchi K, Tomosada A, Matsuo Y (1997) Photosynthesislight response curves in Kuroshio, Oyashio and the transition area off Tohoku. Bull Tohoku Natl Fish Res Inst 59: $127-138$

> Yoshie N, Yamanaka Y (2005) Processes causing the temporal changes in $\mathrm{Si} / \mathrm{N}$ ratios of nutrient consumptions and export flux during the spring diatom bloom. J Oceanogr 61:1059-1073

Yoshie N, Yamanaka Y, Kishi MJ, Saito H (2003) One dimensional ecosystem model simulation of the effects of vertical dilution by the winter mixing on the spring diatom bloom. J Oceanogr 59:563-571

Yoshie N, Fujii M, Yamanaka Y (2005) Ecosystem changes after the SEEDS iron fertilization in the western North Pacific simulated by a one-dimensional ecosystem model. Prog Oceanogr 64:283-306

> Yoshie N, Yamanaka Y, Rose KA, Eslinger DL, Ware DM, Kishi MJ (2007) Parameter sensitivity study of the NEMURO lower trophic level marine ecosystem model. Ecol Model 202:26-37

Yoshikawa T (2002) Studies on photosynthetic characteristics of phytoplankton communities in the sea. PhD dissertation, University of Tokyo

Submitted: December 12, 2007; Accepted: September 17, 2009 Proofs received from author(s): December 11, 2009 